\title{
Description of an early Cretaceous termite (Isoptera: Kalotermitidae) and its associated intestinal protozoa, with comments on their co-evolution

\author{
George O Poinar Jr*
}

Address: Department of Zoology, Oregon State University, Corvallis, Oregon, 97331, USA

E-mail: George O Poinar Jr* - poinarg@science.oregonstate.edu

${ }^{*}$ Corresponding author

Published: 18 February 2009

Received: 20 January 2009

Parasites \& Vectors 2009, 2:12 doi: 10.1186/1756-3305-2-12

Accepted: 18 February 2009

This article is available from: http://www.parasitesandvectors.com/content/2/I/I2

(C) 2009 Poinar; licensee BioMed Central Ltd.

This is an Open Access article distributed under the terms of the Creative Commons Attribution License (http://creativecommons.org/licenses/by/2.0), which permits unrestricted use, distribution, and reproduction in any medium, provided the original work is properly cited.

\begin{abstract}
Background: The remarkable mutualistic associations between termites and protists are in large part responsible for the evolutionary success of these eusocial insects. It is unknown when this symbiosis was first established, but the present study shows that fossil termite protists existed in the Mesozoic.

Results: A new species of termite (Kalotermes burmensis n. sp.) in Early Cretaceous Burmese amber had part of its abdomen damaged, thus exposing trophic stages and cysts of diverse protists. Some protists were still attached to the gut intima while others were in the amber matrix adjacent to the damaged portion. Ten new fossil flagellate species in the Trichomonada, Hypermastigida and Oxymonadea are described in nine new genera assigned to 6 extant families. Systematic placement and names of the fossil flagellates are based on morphological similarities with extant genera associated with lower termites. The following new flagellate taxa are established: Foainites icelus $\mathrm{n}$. gen. n. sp., Spiromastigites acanthodes n. gen. n. sp., Trichonymphites henis n. gen., n. sp., Teranymphites rhabdotis n. gen. n. sp., Oxymonas protus n. sp., Oxymonites gerus n. gen., n. sp., Microrhopalodites polynucleatis n. gen., n. sp., Sauromonites katatonis n. gen., n. sp., Dinenymphites spiris n. gen., n. sp., Pyrsonymphites cordylinis n. gen., n. sp. A new genus of fossil amoeba is also described as Endamoebites proterus n. gen., n. sp. Fourteen additional trophic and encystid protist stages are figured and briefly characterized.

Conclusion: This represents the earliest fossil record of mutualism between microorganisms and animals and the first descriptions of protists from a fossil termite. Discovering the same orders, families and possibly genera of protists that occur today in Early Cretaceous kalotermitids shows considerable behaviour and morphological stability of both host and protists. The possible significance of protist cysts associated with the fossil termite is discussed in regards the possibility that coprophagy, as well as proctodeal trophallaxis, was a method by which some termite protozoa were transferred intrastadially and intergenerationally at this time.
\end{abstract}




\section{Background}

Termites are one of the most successful eusocial insect groups today and certainly the most notorious as a result of their damage to human dwellings. Their success can be attributed in large part to microbial (especially protozoa and bacterial) symbionts harbored in their alimentary tract. Especially important are gut protists, which are essential for the survival of termites feeding on lignocelluloses. While termites do produce endogenous cellulases from salivary glands and gut cells, cellulolytic protists are crucial for the complete digestion of cellulose in wood-feeding termites [1-3]. In the lower termites, these symbionts are mostly flagellates belonging to the Oxymonadida, Trichomonada and Hypermastigida [4-7]. Flagellates associated with an Early Cretaceous lower termite of the family Kalotermitidae are described and compared with mutualistic flagellates of extant kalotermitids. This discovery shows that, while the protist species represent different genera and species, mutualistic associations between protists and termites had already been established some 100 million years ago. The present study represents the earliest fossil record of mutualism between microorganisms and animals [8].

\section{Results}

Description of host termite

Damage to the termite included the loss of the left hind wing, the tip of the abdomen (including the cerci), the right side of the metathorax and the right side of the first three abdominal segments. All wings were flexed at their bases. However, it was possible to determine the venation in the distal three quarters of the right forewing and the complete right hind wing.

Based on the morphological characters of the termite (Sc absent from the hind wing, $\mathrm{R}$ simple in both wings, no reticulation between the veins posterior to $R, R$ separate from the costal margin, presence of a number of regularly spaced oblique forward branches between the Rs and C), the fossil is placed in the family Kalotermitidae $[9,10]$.

Its small size, low number of antennal segments, strongly sclerotized radial sector, unsclerotized $M$ and $\mathrm{Cu}$ veins, complete $M$ vein positioned halfway between Rs and $\mathrm{Cu}$, wing membrane densely covered with minute, pigmented nodules, tibial spurs lacking on the shaft of the mid-tibia and the presence of ocelli and arolia, align the fossil with the genus Kalotermes Hagen $1853[9,10]$. Since the fossil differs from previously described termites in Burmese amber [10-13], it is described below as a new species. It should be noted that the placement of the fossil in the extant genus Kalotermes is tentative since some diagnostic characters (number of apical spines on the tibiae, front wing venation, etc.) were obscured.
Family Kalotermitidae Banks 1919

Genus Kalotermes Hagen 1853

Kalotermes burmensis n. sp. (Figs. 1, 2, 3, 4, 5 and 6)

Alate (sex unknown): Fontanelle absent; head capsule, thorax, legs and abdomen dark brown; length of body (from anterior edge of clypeus to end of abdomen) 3.3 mm; head length, $567 \mu \mathrm{m}$; head width, $607 \mu \mathrm{m}$; eye diameter, $113 \mu \mathrm{m}$; ocellus small, $30 \mu \mathrm{m}$ in diameter; located $62 \mu \mathrm{m}$ from compound eye, length terminal maxillary palp, $135 \mu \mathrm{m}$; length terminal labial palp, 108 $\mu \mathrm{m}$; right mandible with prominent terminal tooth and smaller subterminal tooth; left antennae $850 \mu \mathrm{m}$ in length, with 12 segments, terminal segment smallest; maximum length of pronotum, $525 \mu \mathrm{m}$; minimum length of pronotum, $420 \mu \mathrm{m}$; width of pronotum, $672 \mu \mathrm{m}$; length scale on fore wing, $531 \mu \mathrm{m}$; length scale on hind wing, $292 \mu \mathrm{m}$; length right hind wing, $3.9 \mathrm{~mm}$; width right hind wing, $1.2 \mathrm{~mm}$; venation on right hind wing as follows: Sc not present; $\mathrm{R}$ simple, short; $\mathrm{M}$ with double fork near terminus; wing membrane covered with minute black nodules; 6 branches extend from Rs to C; all branches of cubitus simple except basal one; apical spines on tibia partially obstructed, at least 2 on meso and metatibia; tarsi four-jointed with first three segments short; claws $95 \mu \mathrm{m}$ in length; arolium short; cerci missing.

Holotype: Specimen B-I-2 deposited in the Poinar amber collection maintained at Oregon State University.

Locality: Amber mine in the Hukawng Valley, southwest of Maingkhwan in the state of Kachin $\left(26^{\circ} 20^{\prime} \mathrm{N}, 96^{\circ}\right.$ $36 ' \mathrm{E}$ ) in Myanmar (Burma).

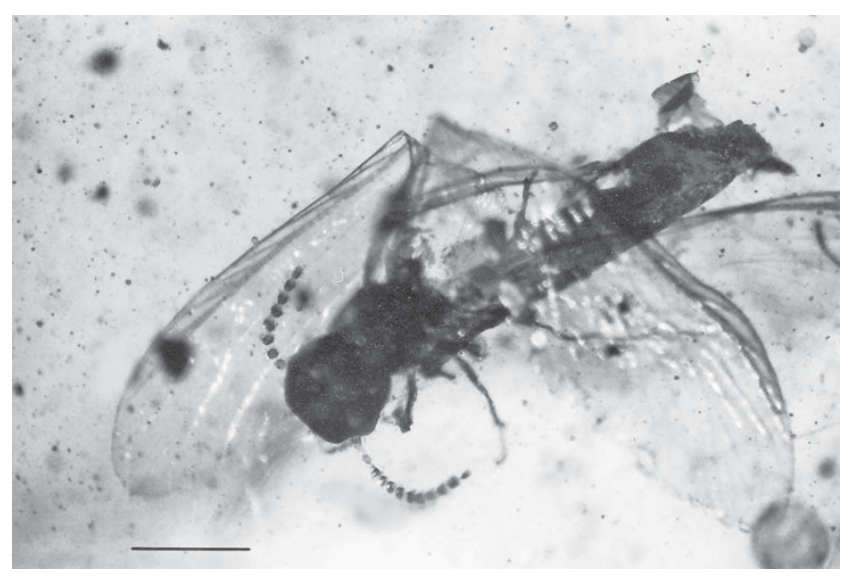

Figure I

Dorsal view of Kalotermes burmensis n. sp. Bar $=690 \mu \mathrm{m}$. 


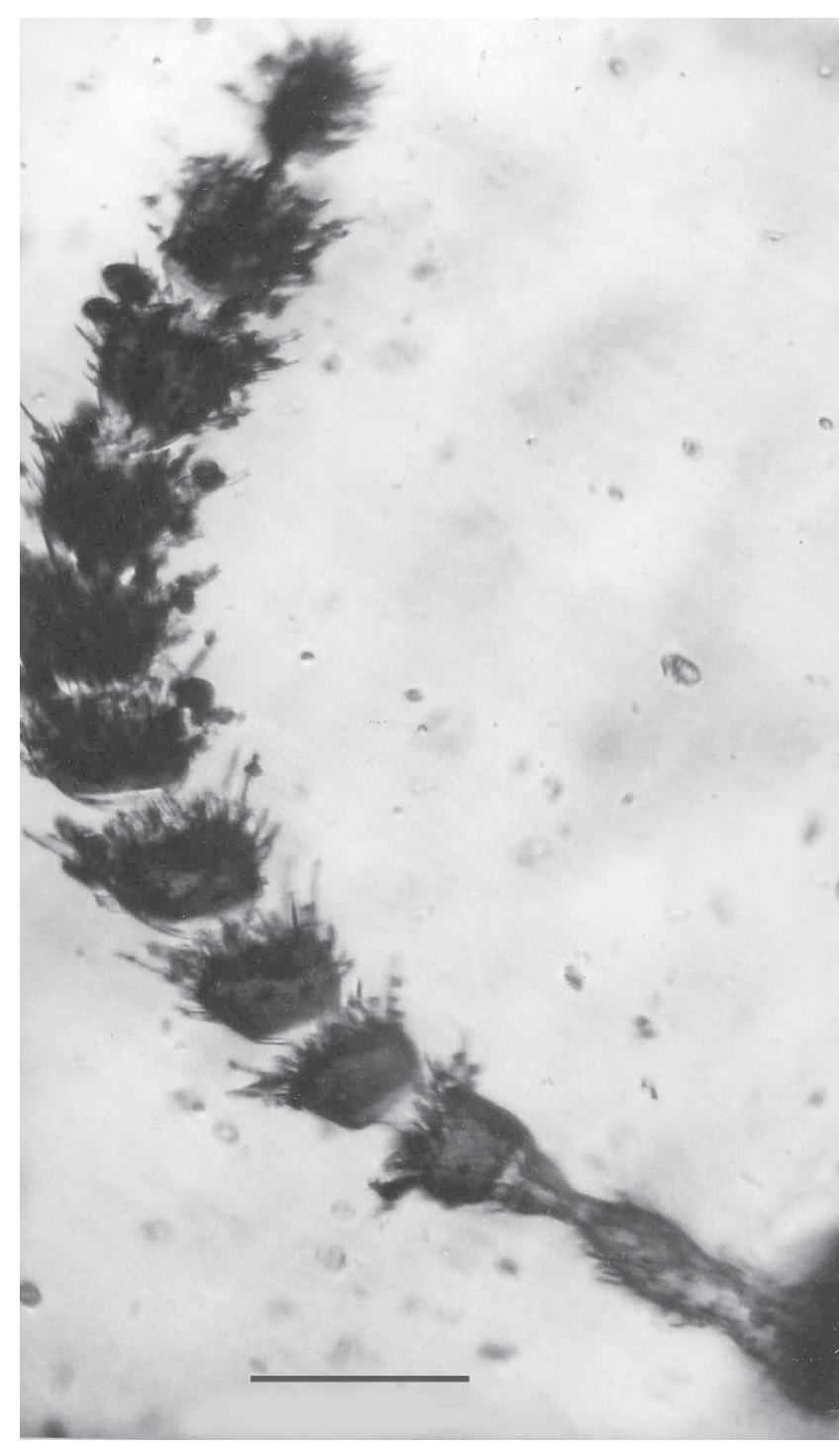

Figure 2

Left antenna of Kalotermes burmensis $\mathbf{n}$. sp. First antennomere partially hidden by head. Bar $=106 \mu \mathrm{m}$.

Comments: The present species differs from Kalotermes swinhoei [11] and $K$. tristis [12], previously described from Burmese amber. While Emerson [14] and Krishna [9] felt that $K$. swinhoei and K. tristis could be synonymous, Williams [10] considered both as valid species and presented diagnostic characters to separate them. The absence of arolia, simple $M$ vein, wing membrane lacking nodules and number of antennal segments separates $K$. tristis from the present species. From $K$. swinhoei, K. burmensis differs in its slightly smaller size $(3.3 \mathrm{~mm}$ vs $3.8 \mathrm{~mm})$, greater eye diameter $(250 \mu \mathrm{m}$ vs $113 \mu \mathrm{m})$, larger head length ( $607 \mu \mathrm{m}$ vs $530 \mu \mathrm{m})$, shorter pronotal width $(672 \mu \mathrm{m}$ vs $760 \mu \mathrm{m})$, shorter terminal maxillary palp (135 $\mu \mathrm{m}$ vs $190 \mu \mathrm{m})$, shorter terminal labial palp

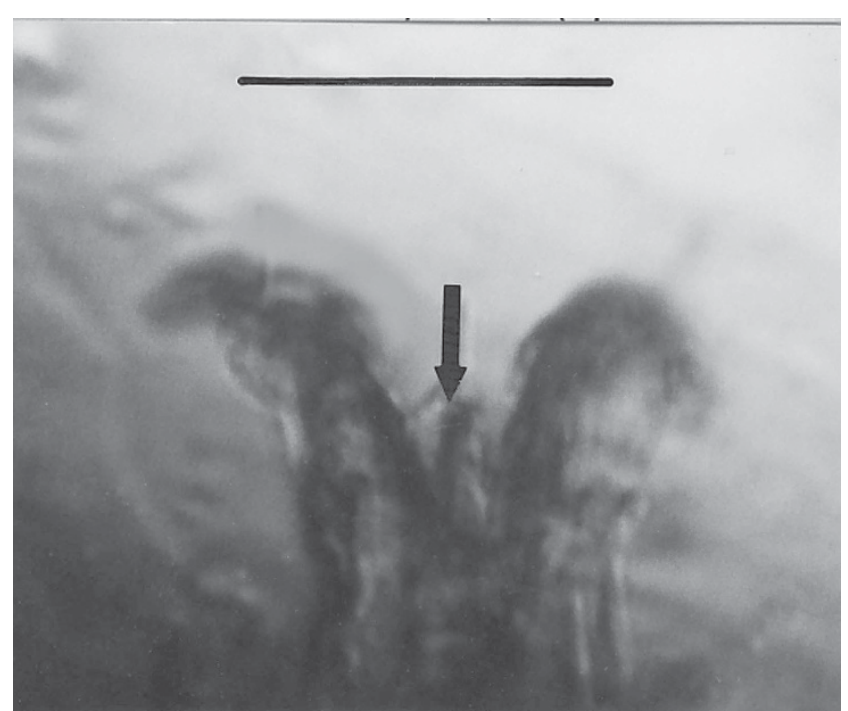

Figure 3

Claw with arolium (arrow) of Kalotermes burmensis $\mathbf{n}$. sp. Bar $=63 \mu \mathrm{m}$.

(108 $\mu \mathrm{m}$ vs $160 \mu \mathrm{m})$, fewer number of antennal segments (12 vs at least 16 ), shorter hind wing ( $3.9 \mathrm{~mm}$ vs $4.8 \mathrm{~mm}$ ), length of $\mathrm{R}$ vein in hind wing (about $1 / 5$ of length in $K$. burmensis and $1 / 3$ of length in K. swinhoei and approximately equal width of the head and pronotum in $K$. burmensis, while the width of the pronotum $(760 \mu \mathrm{m})$ is larger than the head $(530 \mu \mathrm{m})$ in K. swinhoei.

The wing venation, head shape, presence and size of arolia, presence of ocelli, absence of spines on the shaft of the mid-tibia, number of tarsal and antennal segments and presence of pigmented wing nodes separates $K$. burmensis from the four Burmese amber specimens described by Engel et al, [13], as well as all of the Tertiary species of kalotermitids [14].

\section{Description of protists}

A variety of protists were associated with $K$. burmensis. Some were still attached to the gut lining, while others were free in the amber matrix adjacent to the exposed gut. Those that revealed morphological characters similar to protist families and genera found in extant lower termites are described below. Since the amber matrix normally contains a variety of small, oval-spherical bodies, care was taken to select for descriptions only protozoa attached to the gut intima or with features aligning them with extant groups associated with lower termites. None of the forms presented below are considered to be insect parasites or pathogens [15]. Stages that could not be identified due to insufficient characters are documented with photographs and briefly characterized. 


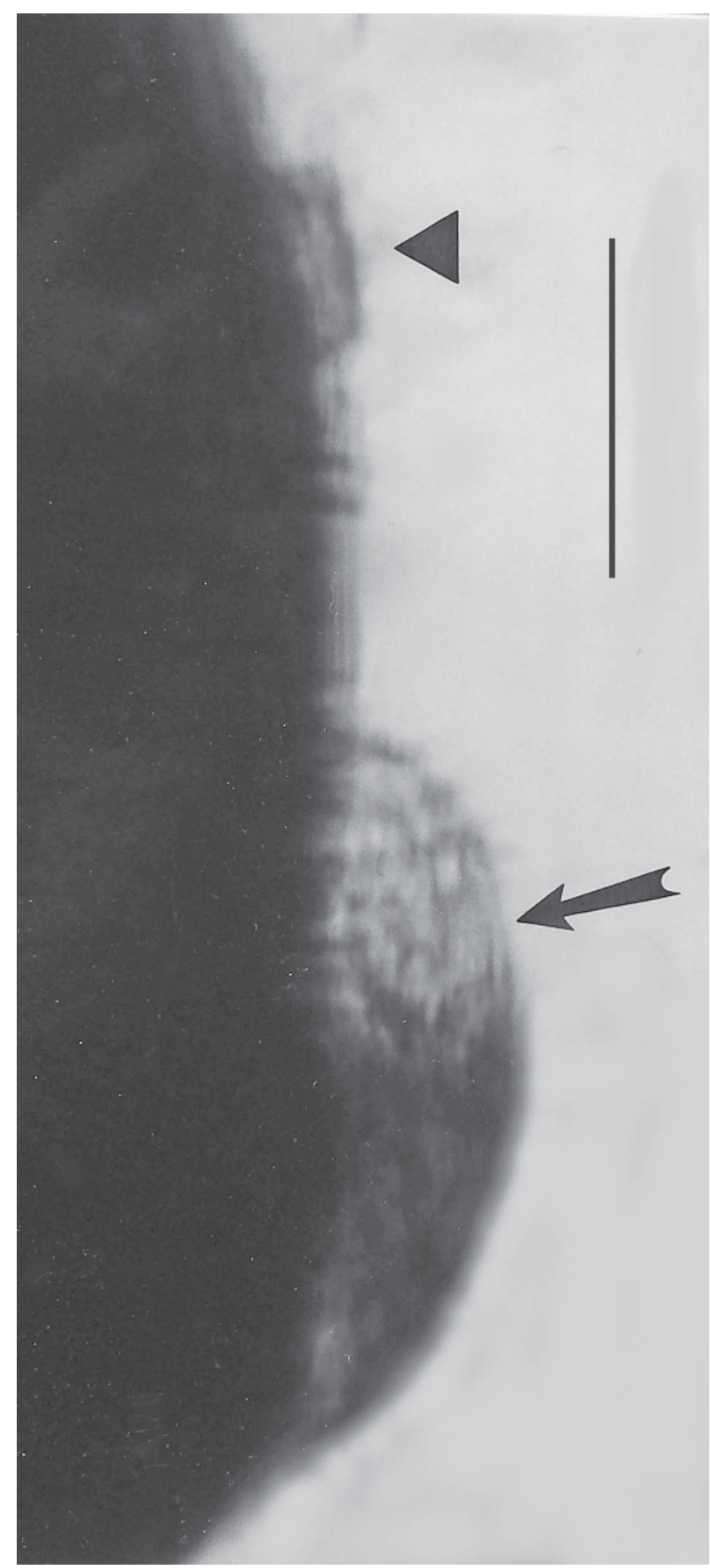

Figure 4

Lateral view of head of Kalotermes burmensis $\mathbf{n}$. sp. showing ocellus (arrowhead) and compound eye (arrow). Bar $=50 \mu \mathrm{m}$.

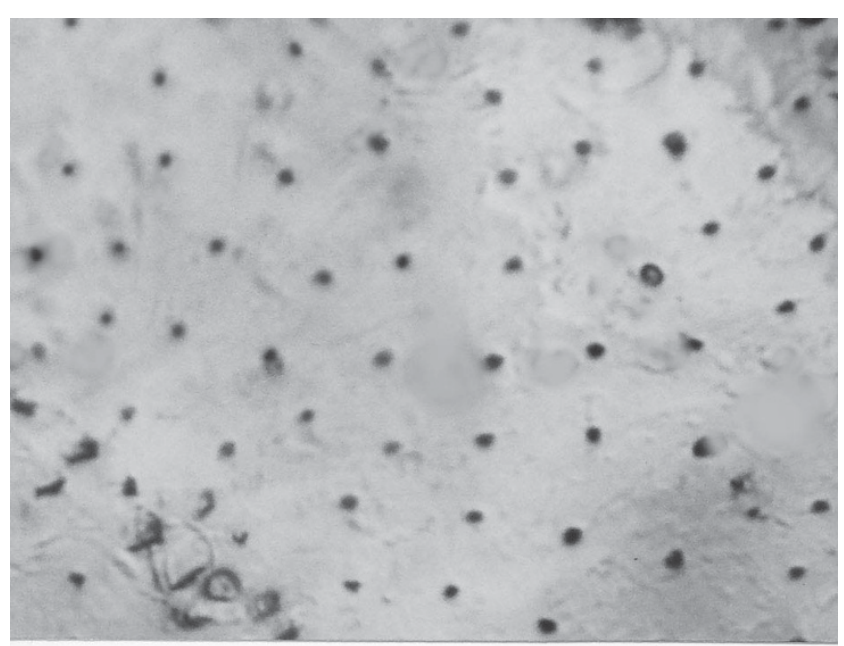

\section{Figure 5}

Minute black nodules covering wing membrane of Kalotermes burmensis $\mathbf{n}$. sp.

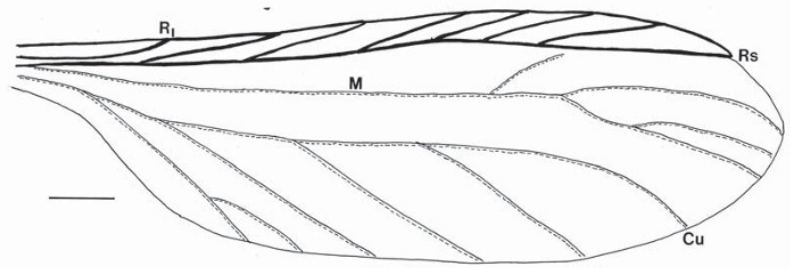

\section{Figure 6}

Hind wing of Kalotermes burmensis $\mathbf{n}$. sp. showing radius $\left(R_{1}\right)$, radial sector $(R s)$, medial $(M)$, and cubital $(C u)$ veins. Bar $=328 \mu \mathrm{m}$.

Except for one species described in the extant genus Oxymonas, all of the protists are placed in fossil genera, with names based on extant genera with similar morphological characters. However, it is acknowledged that since not all diagnostic characters could be determined in the fossil protists and features that were present could align the fossil with more than one extant protist lineage, the similarities so indicated between the fossils and extant genera are only tentative.

Terminology and classification generally follows that of Brugerolle and Lee [4, 5] and Patterson et al. [16]. A synopsis of the described fossils with their higher level systematic positions are summarized below. 

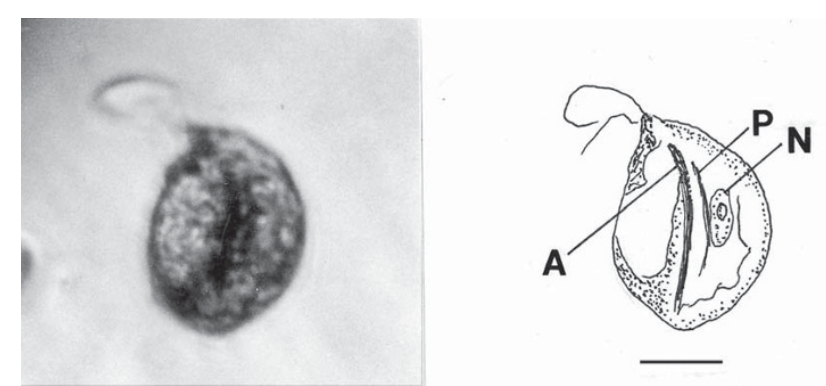

\section{Figure 7}

Photo and drawing of Foainites icelus n. gen. n. sp. $N=$ nucleus, $\mathrm{A}=$ axostyle, $\mathrm{P}=$ parabasal. $\mathrm{Bar}=12 \mu \mathrm{m}$.

Phylum Parabasalia

Class Trichomonada Kirby

Order Trichomonadida Kirby

Family Devescovinidae Doflein

Foainites icelus n. gen., n. sp. (Figs. 7A,B)

Class Hypermastigida Grassi \& Foá

Order Spirotrichonymphida Light

Family Holomastigotidae Grassi

Spiromastigites acanthodes n. gen., n. sp. (Figs. 8A,B)

Order Trichonymphida Poche

Family Trichonymphidae Kent

Trichonymphites henis n. gen., n. sp. (Figs. 9A,B)

Family Teranymphidae Koidzumi

Teranymphites rhabdotis n. gen., n. sp. (Figs. 10A,B)

Phylum Oxymonada

Class Oxymonadea Grassi

Order Oxymonadida Grassi

Family Oxymonadidae Kirby

Oxymonas Janicki

O. protus n. sp. (Figs. 11A,B)
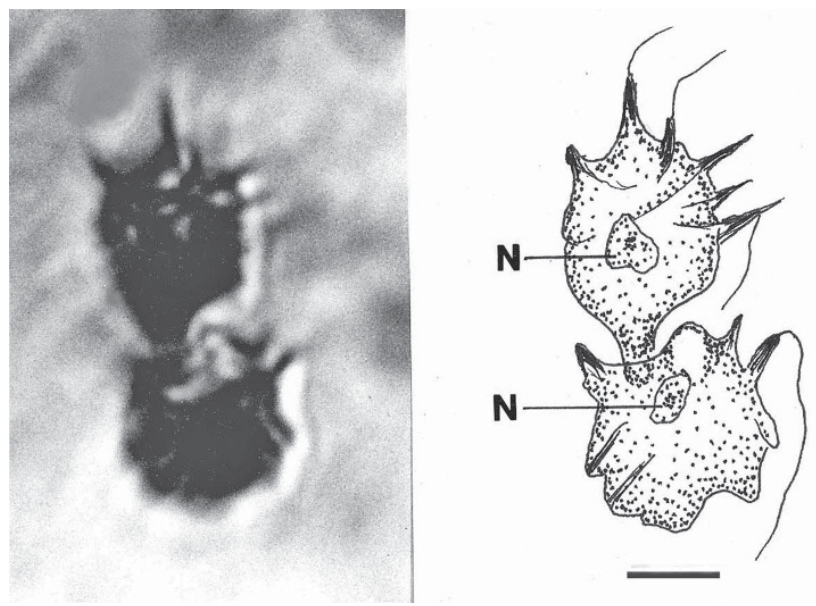

Figure 8

Photo and drawing of Spiromastigites acanthodes $\mathbf{n}$. gen., n. sp. $\mathrm{N}=$ nucleus. $\mathrm{Bar}=5 \mu \mathrm{m}$.
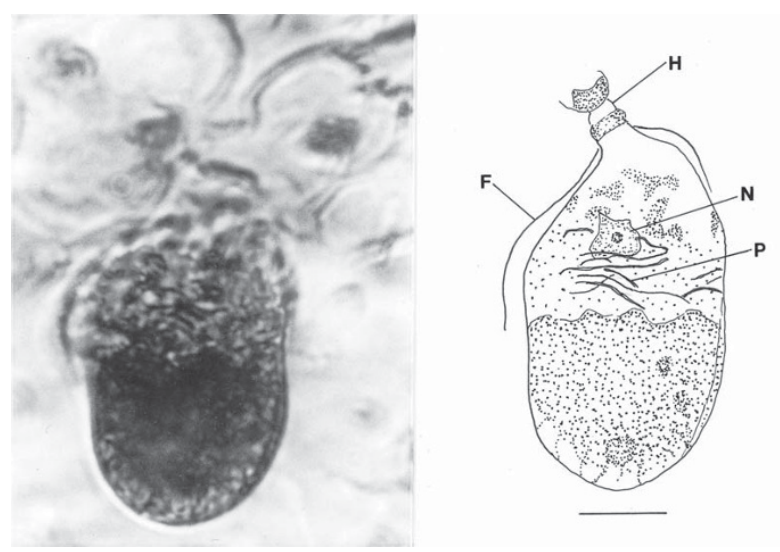

Figure 9

Photo and drawing of Trichonymphites henis n. gen., $\mathbf{n}$. sp. $\mathrm{H}=$ holdfast, $\mathrm{F}=$ rostral flagellum, $\mathrm{n}=$ putative nucleus. Bar $=$ II $\mu \mathrm{m}$.

Oxymonites gerus n. gen., n. sp. (Figs. 12A,B) Microrhopalodites polynucleatis n. gen., n. sp.(Figs. 13A,B) Sauromonites katatonis n. gen., n. sp. (Figs. 14A,B)

Family Pyrsonymphidae Grassi

Dinenymphites spiris n. gen., n. sp. (Figs. 15A,B)

Pyrsonymphites cordylinis n. gen., n. sp. (Figs. 16A,B)

"Sarcodina"

Amoeba of uncertain affinity

Endamoebites proterus n. gen., n. sp. (Figs. 17A,B)

Family Devescovinidae Doflein, 1911

Foainites Poinar, n. gen. (Figs. 7A,B)

Description. Body asymmetrical; two anterior flagella (more could be present) arising from anterior area;
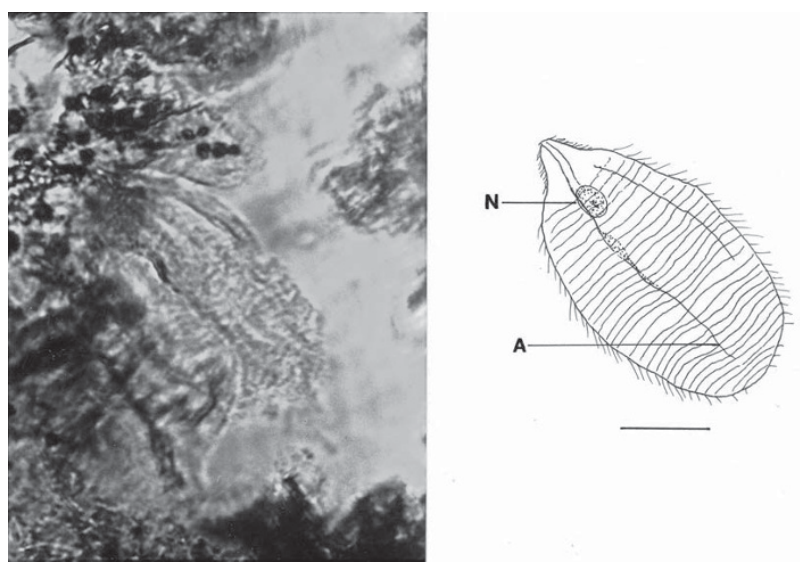

\section{Figure 10}

Photo and drawing of Teranymphites rhabdotis $\mathbf{n}$. gen. n. sp. Left portion of body covered by a second specimen. $\mathrm{N}=$ nucleus, $\mathrm{A}=$ putative axostyle, $\mathrm{P}=$ parabasal. $\mathrm{Bar}=24 \mu \mathrm{m}$. 

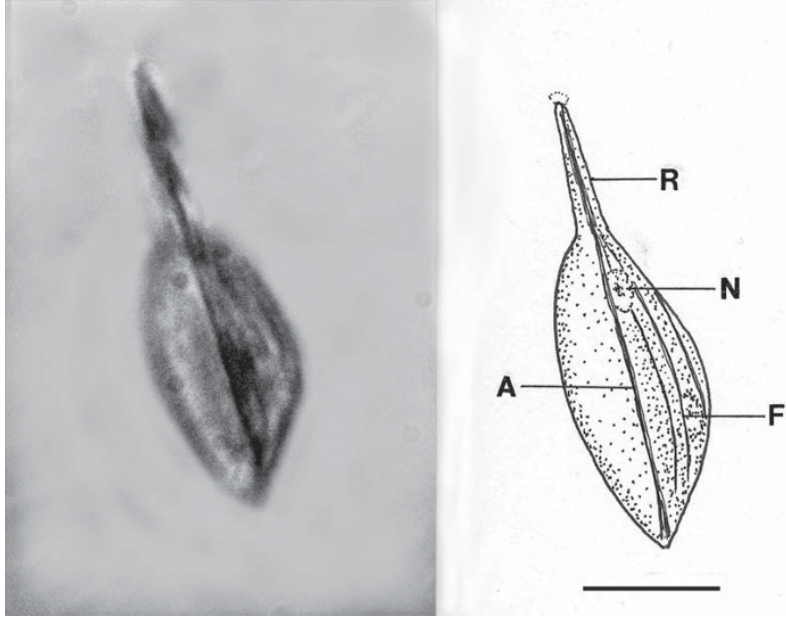

\section{Figure I I}

Photo and drawing of Oxymonas protus n. sp. $\mathrm{R}=$ rostellum, $\mathrm{N}=$ nucleus, $\mathrm{A}=$ putative axostyle, $\mathrm{F}=$ fibrous structure. Bar $=15 \mu \mathrm{m}$.
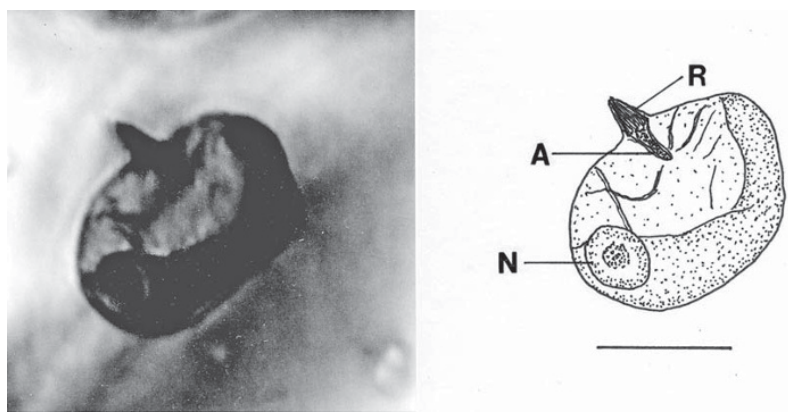

Figure 12

Photo and drawing of Oxymonites gerus n. gen., n. sp. $\mathrm{R}=$ rostellum, $\mathrm{A}=$ axostyle, $\mathrm{N}=$ nucleus. $\mathrm{Bar}=26 \mu \mathrm{m}$.
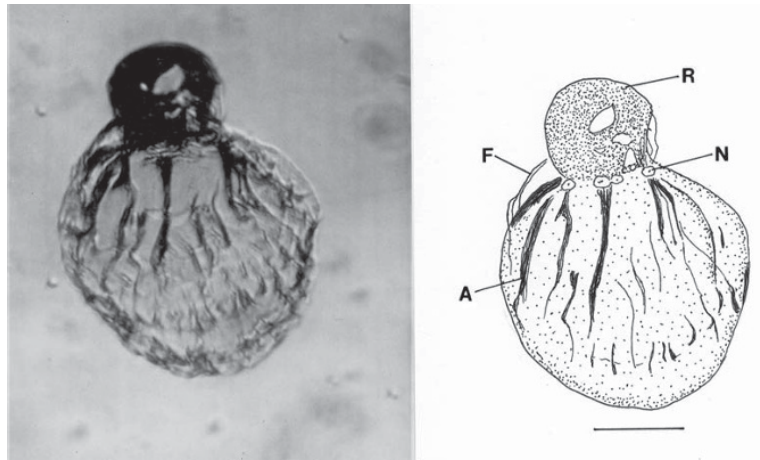

Figure 13

Photo and drawing of Microrhopalodites polynucleatis n. gen., n. sp. $R=$ rostellum, $A=$ axostyle, $N=$ nucleus, Bar $=4 \mathrm{I} \mu \mathrm{m}$.
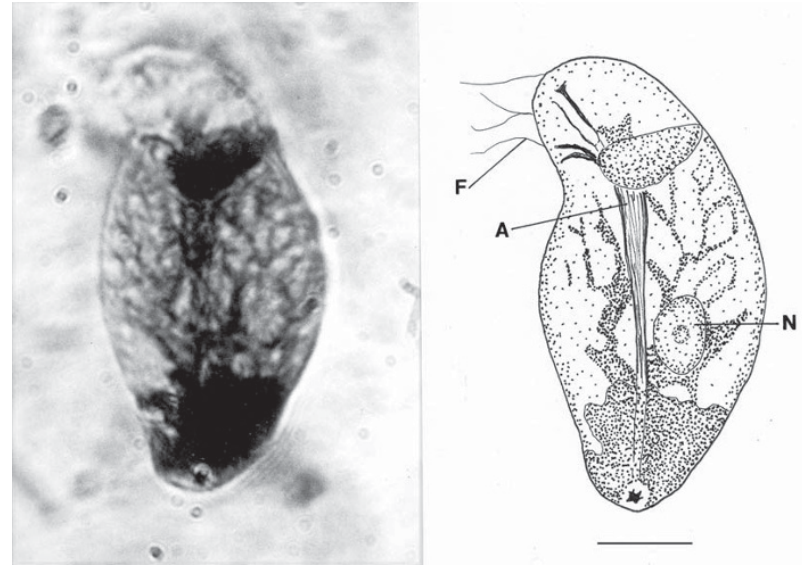

Figure 14

Photo and drawing of Sauromonites katatonis n. gen., n. sp. $\mathrm{F}=$ flagellum, $\mathrm{A}=$ axostyle, $\mathrm{N}=$ nucleus. $\mathrm{Bar}=22 \mu \mathrm{m}$.
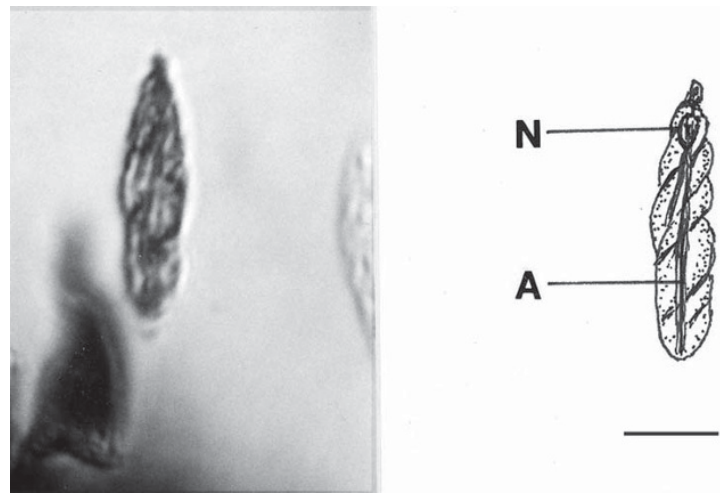

Figure 15

Photo and drawing of Dinenymphites spiris $\mathbf{n}$. gen., $\mathbf{n}$. sp. $\mathrm{N}=$ nucleus, $\mathrm{A}=$ axostyle, $\mathrm{Bar}=13 \mu \mathrm{m}$.

trailing flagellum apparently in front of body; nucleus located in middle of body; parabasal body straight, not coiled around nucleus; axostyle extending through body.

Type species. Foainites icelus n. sp.

Foainites icelus Poinar, n. sp.

Description. Length, $31 \mu \mathrm{m}$; width, $23 \mu \mathrm{m}$; length of longest flagellum, $24 \mu \mathrm{m}$; parabasal body rod-shaped; axostyle not protruding from body.

Etymology: From the Greek "ikelos" meaning similar, in regards to the body shape resembling extant species of Foaina Janicki. 

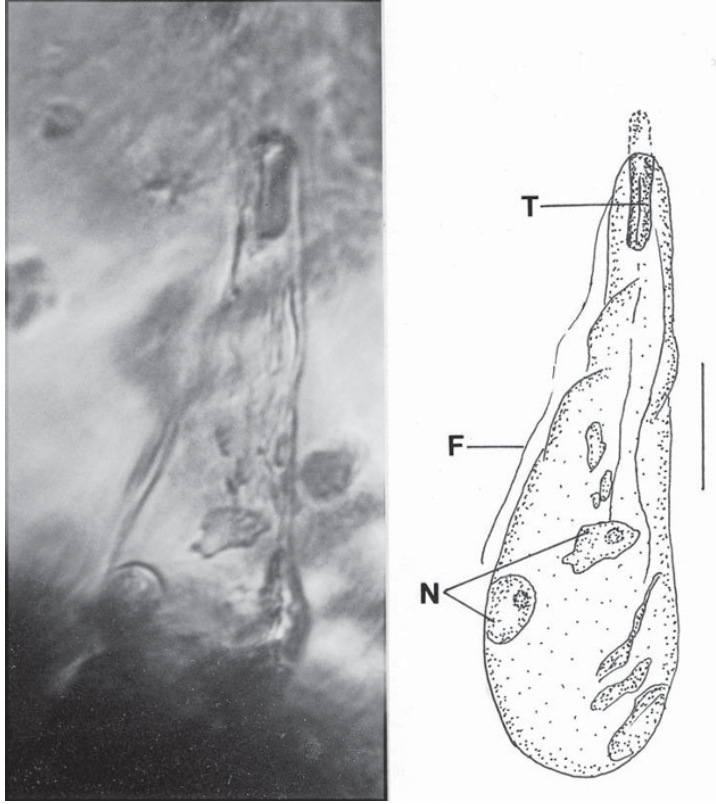

Figure 16

Photo and drawing of Pyrsonymphites cordylinis n. gen., n. sp. $\mathrm{F}=$ flagellum, $\mathrm{T}=$ tubular area, $\mathrm{N}=$ nucleus. Bar $=21 \mu \mathrm{m}$.
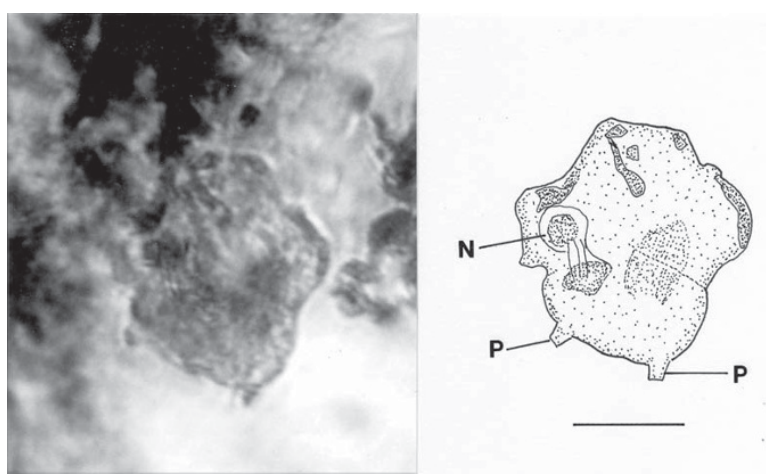

Figure 17

Photo and drawing of Endamoebites proterus n. gen., n. sp. $\mathrm{P}=$ protuberance, $\mathrm{N}=$ nucleus dividing. $\mathrm{Bar}=14 \mu \mathrm{m}$.

Holotype: Specimen (accession \# B-I-2) deposited in the Poinar amber collection maintained at Oregon State University.

Locality: Amber mine in the Hukawng Valley, southwest of Maingkhwan in Kachin state $\left(26^{\circ} 20^{\prime} \mathrm{N}, 96^{\circ} 36^{\prime} \mathrm{E}\right)$, Myanmar (Burma).

Comments: The fossil resembles the body shape of extant species of Foaina Janicki 1915, however, it could be related to one of the other genera of small devescovinids. The straight parabasal body slightly longer than the nucleus distinguishes it from extant species. All known species of Foaina, whose size range extends from $6 \mu \mathrm{m}$ to $59 \mu \mathrm{m}$, occur in kalotermitids [5, 9].

Family Holomastigotidae Grassi, 1892

Spiromastigites Poinar n. gen. (Figs. 8A,B)

Description. Body bearing emergent processes (spines), some of which bear flagella at their tips; axostyle not observed; rostrum absent; nucleus positioned at midbody.

Type species: S. acanthodes n. sp.

Spiromastigites acanthodes Poinar n. sp.

Description. Two adjacent individuals, upper individual (17 $\mu \mathrm{m}$ in length) with terminal process connected to girdle of lower individual (14 $\mu \mathrm{m}$ in length).

Holotype: Specimen B-I-2 deposited in the Poinar amber collection maintained at Oregon State University.

Locality: Amber mine in the Hukawng Valley, southwest of Maingkhwan in the state of Kachin $\left(26^{\circ} 20^{\prime} \mathrm{N}, 96^{\circ}\right.$ 36'E) in Myanmar (Burma).

Etymology: From the Greek "akantha" for thorn, in reference to the processes on the body surface.

Comment: These two fossils are difficult to classify. Their spiraled flagellar rows and absence of an axostyle and rostrum show similarities to members of the extant genus Spiromastigotes Duboscq \& Grassé, 1943, but the nucleus is anterior in the latter genus. It is not known whether the pair are conjugating or in the final stage of binary fission. The type species of Spiromastigotes is 10$20 \mu \mathrm{m}$ in length and occurs in the hodotermitid, Anacanthotermes ochraceus (Brugerolle \& Lee, 2000b).

Family Trichonymphidae Kent, 1880

Trichonymphites Poinar n. gen. (Figs. 9A,B).

Description. Body short and broad; rostrum short; holdfast attached to intima of termite intestine; rostral flagella (only 2 visible) extend slightly over one half body length; axostyle not seen; putative nucleus positioned in upper third of body; parabasal bodies ribbonshaped, haphazardly positioned in area surrounding nucleus.

Type species: T. henis n. sp. 


\section{T. henis Poinar n. sp.}

Description. Body acorn-shaped, length, $49 \mu \mathrm{m}$; width, $25 \mu \mathrm{m}$; posterior portion of body apparently filled with endoplasmic inclusions.

Holotype: Specimen B-I-2 deposited in the Poinar amber collection maintained at Oregon State University.

Locality: Amber mine in the Hukawng Valley, southwest of Maingkhwan in the state of Kachin $\left(26^{\circ} 20^{\prime} \mathrm{N}, 96^{\circ}\right.$ 36'E) in Myanmar (Burma).

Etymology: From the Greek "henos" for old.

Comment: This genus is placed in the family Trichonymphidae based on its relatively short rostral flagella, absence of an axostyle, and ribbon-like parabasals associated with the nucleus. One of three cysts of this or a related species in the same family is shown in Fig. 19. Members of the genus Trichonympha occur in at least 16 termite genera worldwide, including Kalotermes $[9,17,18]$. Because of its wide distribution in the termite families Hodotermitidae, Rhinotermitidae and Kalotermitidae, Kirby [17] suspected that species of Trichonympha were already present in the various termite lineages

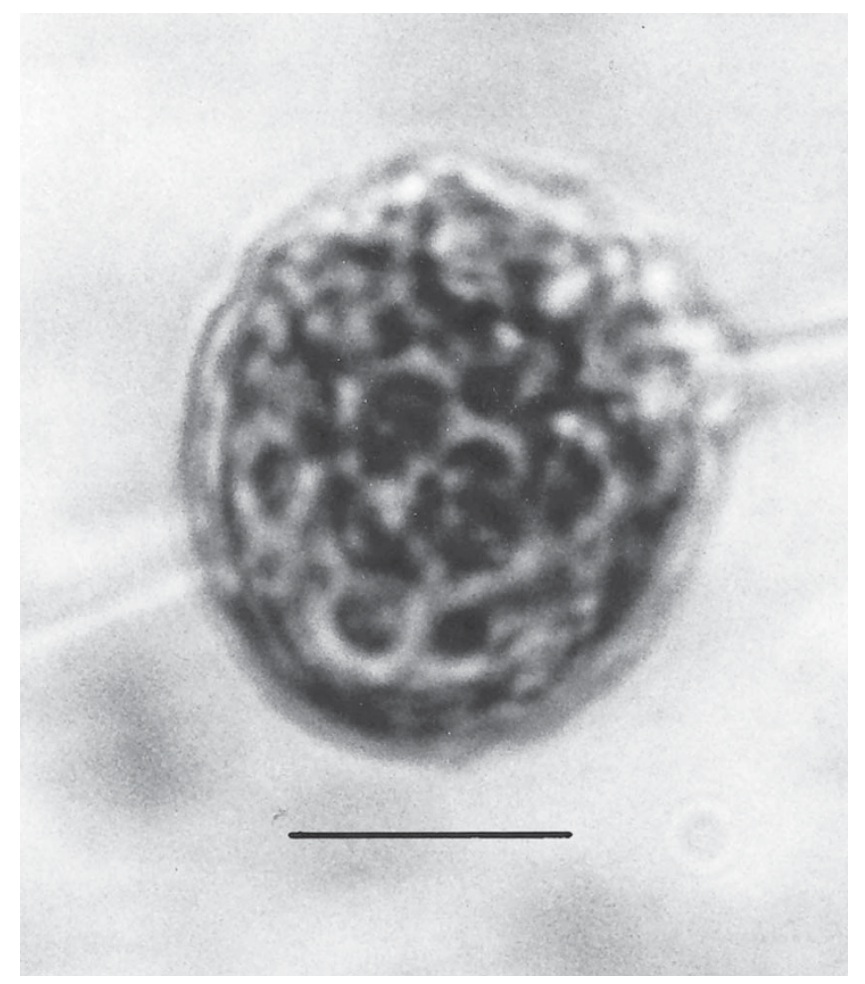

Figure 18

Possible amoebic cyst. Bar $=24 \mu \mathrm{m}$. when they first appeared and then underwent a period of co-evolution that is continuing today.

Family Teranymphidae Koidzumi, 1917

Teranymphites Poinar n. gen. (Figs. 10A,B)

Description. Medium sized oval cell, with short rostrum attached to intestinal cells of host; rostral flagella short; post-rostral area with parallel flagellar rings without connections and giving the cell a segmented appearance; nucleus located under rostral area; putative axostyles (possibly 2) narrow, fiber-like.

Type species: T. rhabdotis n. sp.

Teranymphites. rhabdotis Poinar, n. sp.

Description: Body length, $84 \mu \mathrm{m}$; body width, $46 \mu \mathrm{m}$; rostrum with rows of short flagella; post-rostral area with at least 30 parallel rows of flagella separated by ectoplasmic bands; parabasal body short.

Holotype: Specimen B-I-2 deposited in the Poinar amber collection maintained at Oregon State University.

Locality: Amber mine in the Hukawng Valley, southwest of Maingkhwan in the state of Kachin $\left(26^{\circ} 20^{\prime} \mathrm{N}, 96^{\circ}\right.$ $36 ' \mathrm{E})$ in Myanmar (Burma).

Etymology: From the Greek "rhabdotos" for lined.

Comment: Flagella inserted on parallel rows separated by ectoplasmic bands is a condition found in members of the extant genus Teranympha Koidzumi 1917. The long rostral flagella that also characterize this genus may be hidden since the anterior end of the fossil is attached to the gut intima. Long, narrow, fibril axostyles occur in the related extant genus Spirotrichosoma Sutherland 1933 and both genera have an anterior nucleus. Extant species of Teranympha and Spirotrichosoma range from 90-270 $\mu \mathrm{m}$ and 55-395 $\mu \mathrm{m}$ in length, respectively, and occur in members of the families Rhinotermitidae and Termopsidae, respectively [5].

Family Oxymonadidae Kirby, 1928

Oxymonas Janicki, 1915

Oxymonas protus n. sp. (Figs. 11A,B)

Description. Body spindle shaped; length (including rostellum), $50 \mu \mathrm{m}$, width, $15 \mu \mathrm{m}$, length rostellum, 17 $\mu \mathrm{m}$; anterior nucleus approx $7 \mu \mathrm{m}$ in longest dimension, positioned at base of rostellum; body with supporting 
fibers attached at base of rostellum; single axostyle extends length of body; faint holdfast at tip of rostellum.

Holotype: Specimen B-I-2 deposited in the Poinar amber collection maintained at Oregon State University.

Locality: Amber mine in the Hukawng Valley, southwest of Maingkhwan in the state of Kachin $\left(26^{\circ} 20^{\prime} \mathrm{N}, 96^{\circ}\right.$ $36^{\prime} \mathrm{E}$ ) in Myanmar (Burma).

Etymology: From the Greek" protos" for first regarding its fossil status.

Comment: The presence of an anterior rostellum with associated fibers and the uninucleate condition are diagnostic characters of the genus Oxymonas. However members of Oxymonas usually have 4 flagella arising from the shoulder area, which are not evident in the fossil $[4,19]$. Species of Oxymonas occur in at least 10 genera of kalotermitids and range from 5-165 $\mu \mathrm{m}$ in length $[5,9]$. The holdfast is used to attach the cell to the chitinous lining of the termite gut and the size of the rostellum has been used to estimate the density of populations in termite guts, with a lengthy rostellum indicating a crowded condition [19].

\section{Oxymonites Poinar n. gen. (Figs.12A,B)}

Description. Uni-nucleated flagellate with body comprising a single karyomastigont; body wider than long; axostyle short, not extending more than half body length; nucleus large, located near middle of body; rostellum with several fiber bundles.

Type species: O. gerus n. sp.

Oxymonites gerus Poinar n. sp.

Description. Length, $41 \mu \mathrm{m}$; width, $51 \mu \mathrm{m}$; rostellum short, $8 \mu \mathrm{m}$ in length; rostellum without associated fibrous structures; nucleus spherical, $11 \mu \mathrm{m}$ in diameter.

Holotype: Specimen B-I-2 deposited in the Poinar amber collection maintained at Oregon State University.

Locality: Amber mine in the Hukawng Valley, southwest of Maingkhwan in the state of Kachin $\left(26^{\circ} 20^{\prime} \mathrm{N}, 96^{\circ}\right.$ $36^{\prime} \mathrm{E}$ ) in Myanmar (Burma).

Etymology: From the Greek "geros" for old age.

Comments: The presence of an anterior rostellum with fibers arising from the base of the attachment point and the single nucleus is why this fossil was placed in the Oxymonadidae. While oxymonidids typically have an anteriorly placed nucleus, during certain phases, the nucleus may be located in the posterior portion of the body [19]. The shape and size of the rostellum vary greatly in extant oxymonadids [19]. The family is widely distributed in kalotermitids, with some 27 species described worldwide [9]. Possible cysts of this fossil and/or Oxymonas protus are shown in Figs. 19 and 20. Each cyst contains a nucleus and the one in Fig. 19 shows an axostyle in the lower portion of the body, which is characteristic of some oxymonadid cysts [20].

Microrhopalodites Poinar n. gen. (Figs. 13A,B)

Description. Large multinucleated flagellate with corona containing several karyomastigotes with small, anteriorly positioned nuclei; base of rostral area with filaments that extend posteriorly as axostyles; flagella attached at base of rostellum extend at least to midbody; rostral area hemi-spherical in shape.

Type species: M. polynucleatis $\mathrm{n}$. sp.

\section{M. polynucleatis Poinar, n. sp.}

Description: Large cell, with knob-shaped anterior rostral area; total length, $159 \mu \mathrm{m}$; greatest width, $116 \mu \mathrm{m}$; length rostral area, $47 \mu \mathrm{m}$; width rostral area, $52 \mu \mathrm{m}$; at

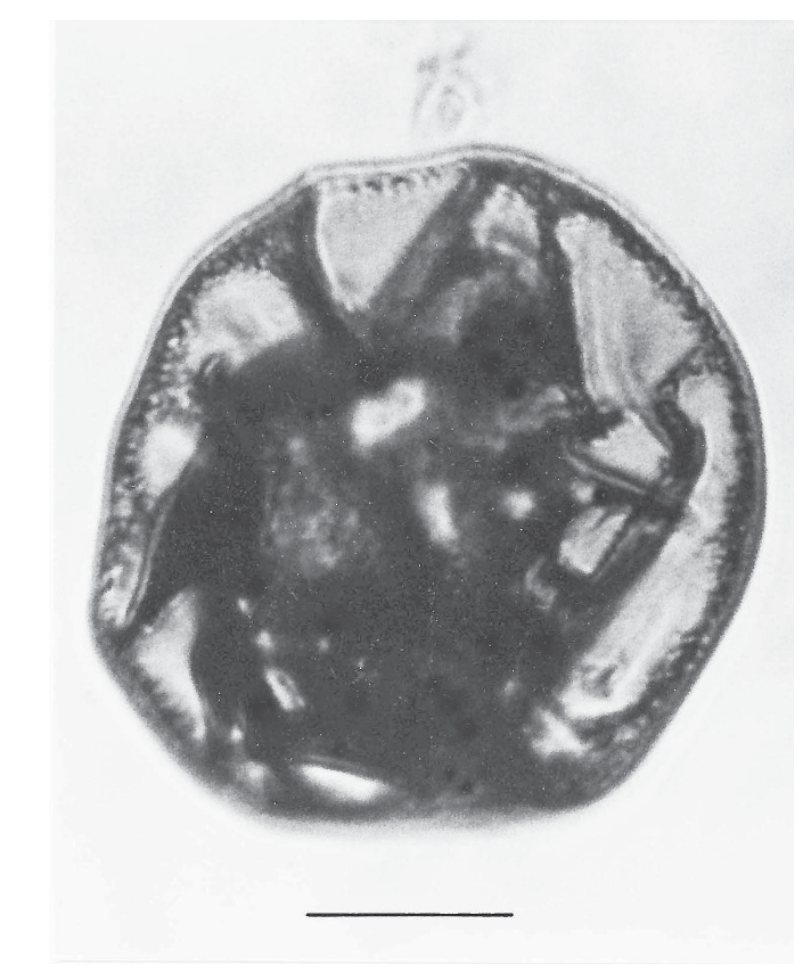

Figure 19

Large spherical cyst with two nuclei. Bar $=28 \mu \mathrm{m}$. 


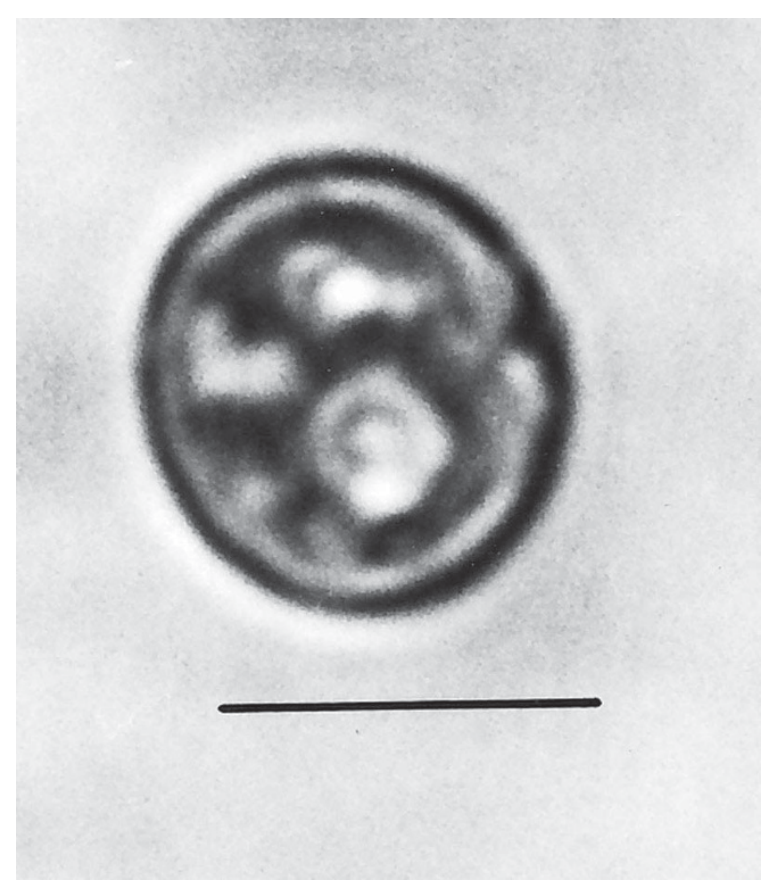

Figure 20

Small spherical cyst with a pair of nucleated cells. Bar $=14 \mu \mathrm{m}$.

least 3 small nuclei positioned at base of rostral area; flagella attached to corona area beneath base of rostellum.

Holotype: Specimen B-I-2 deposited in the Poinar amber collection maintained at Oregon State University.

Locality: Amber mine in the Hukawng Valley, southwest of Maingkhwan in the state of Kachin $\left(26^{\circ} 20^{\prime} \mathrm{N}, 96^{\circ}\right.$ 36'E) in Myanmar (Burma).

Etymology: From the Greek "poly" indicating many nuclei.

Comment: The corona of several karyomastigotes with small nuclei, the large size and the modified rostral area align the fossil with the extant genus Microrhopalodina Grassi \& Foa. This genus contains four extant species ranging in size from $20 \mu \mathrm{m}-165 \mu \mathrm{m}$ and all occur in kalotermitid termites [4]. It is difficult to say if the rounded rostral region is characteristic of the mature trophozoite or if the cell was entering a resting stage. Superficially, this fossil has the appearance of an eugregarine sporont, with the rostral area corresponding to the protomerite and the basal portion the deutomerite. However, there is no scar on the top of the hemispherical rostral area that would indicate the attachment of an epimerite, no evidence of a septum separating the two parts and no evidence of a large nucleus in the portion that would correspond to the deutomerite. The putative flagella and small nuclei associated with the rostral area are not characteristic of eugregarine sporonts, certainly not those from extant termites $[21,22]$.

Sauromonites Poinar n. gen. (Figs. 14A,B).

Description. Axostyle prominent, thickened anteriorly, extending length of body; 4 flagella emerging from rostral area; nucleus located in lower half of body; large dark body at base of rostral area (macronucleus?); network of apparent fiber bundles throughout body; minute dark area at posterior end may represent tip of axostyle.

Type species: Sauromonites katatonis sp. $\mathrm{n}$.

Sauromonites katatonis Poinar sp. n.

Description. Length,106 $\mu \mathrm{m}$; width approximately $1 / 2$ length; length rostral area, $27 \mu \mathrm{m}$; width at base of rostral area, $36 \mu \mathrm{m}$; nucleus large, greatest diameter, $13 \mu \mathrm{m}$.

Holotype: Specimen (accession \# B-I-2) deposited in the Poinar amber collection maintained at Oregon State University.

Locality: Amber mine in the Hukawng Valley, southwest of Maingkhwan in the state of Kachin $\left(26^{\circ} 20^{\prime} \mathrm{N}, 96^{\circ}\right.$ 36'E) in Myanmar (Burma).

Etymology. From the Greek "katatonos" meaning broader than high.

Comments: This species is roughly the same size and shape as extant species of Sauromonas in kalotermitids [4].

Family Pyrsonymphidae Grassi, 1892

Dinenymphites Poinar n. gen. (Figs. 15A,B)

Description. Small rod-shaped, spindle cell with at least 4 spirally twisted flagellar cords adhering to body; small holdfast; axostyle slender; nucleus in anterior portion of body.

Type species: Dinenymphites spiris n. sp.

Dinenymphites spiris Poinar, n. sp.

Description. Body slender, $41 \mu \mathrm{m}$ in length, $9 \mu \mathrm{m}$ in width; axostyle extending length of cell.

Holotype: Specimen B-I-2 deposited in the Poinar amber collection maintained at Oregon State University. 
Locality: Amber mine in the Hukawng Valley, southwest of Maingkhwan in the state of Kachin $\left(26^{\circ} 20^{\prime} \mathrm{N}, 96^{\circ}\right.$ $36^{\prime} \mathrm{E}$ ) in Myanmar (Burma).

Etymology: From the Greek "speira" for twisted in reference to the body structure.

Comments: The fossil resembles extant species of the genus Dinenympha Leidy, which range from $24 \mu \mathrm{m}$ to 64 $\mu \mathrm{m}$ in length. Members of this genus are now considered motile forms of Pyrsonympha Leidy [4].

Pyrsonymphites Poinar, n. gen. (Figs. 16A,B)

Description. Large club-shaped, slightly spirally twisted flagellate with two nuclei positioned slightly below midbody; with several flagella (some adhering to cell body) arising from anterior end of cell; anterior tip with thickened tubular area; axostyle not detected.

Type species: P. cordylinis n. sp.

Pyrsonymphites cordylinis Poinar, n. sp.

Description. Length, $152 \mu \mathrm{m}$; width, $48 \mu \mathrm{m}$; length longest flagellum, $98 \mu \mathrm{m}$; length cephalic tube, $24 \mu \mathrm{m}$; tubular area (holdfast?) inserted in host's intestinal intima.

Holotype: Specimen B-I-2 deposited in the Poinar amber collection maintained at Oregon State University.

Locality: Amber mine in the Hukawng Valley, southwest of Maingkhwan in the state of Kachin $\left(26^{\circ} 20^{\prime} \mathrm{N}, 96^{\circ}\right.$ 36'E) in Myanmar (Burma).

Etymology: From the Greek " kordylinas" for clubshaped in reference to the shape of the fossil.

Comment: This fossil resembles the extant Pyrsonympha Leidy regarding the position of the flagella and posterior nucleus. The two cells in the lower body appear to be nuclei. Attached pyriform cells of Pyrsonympha range between 150 $\mu \mathrm{m}$ and $200 \mu \mathrm{m}$, which is within the size of the fossil. Dinenymphites spiris could be the unattached stage of this or another species of Pyrsonympha. Members of Pyrsonympha occur today in members of the Rhinotermitidae [4].

\section{"Sarcodina"}

Amoebae of uncertain affinities (Patterson et al., 2000).

Endamoebites Poinar n. gen. (Figs. 17A,B).

Description. Spherical nucleus in process of dividing; nucleolus not apparent; body amoeboid-like, nearly spherical, with broad pseudopodia and short protuberances.

Type species: Endamoebites proterus n. sp.

Endamoebites proterus Poinar n. sp.

Description. Greatest diameter, $33 \mu \mathrm{m}$; nucleus undergoing division; diameter of upper nucleus, $8 \mu \mathrm{m}$; endoplasm containing particles of various sizes.

Holotype: Specimen B-I-2 deposited in the Poinar amber collection maintained at Oregon State University.

Locality: Amber mine in the Hukawng Valley, southwest of Maingkhwan in the state of Kachin $\left(26^{\circ} 20^{\prime} \mathrm{N}, 96^{\circ}\right.$ $36^{\prime} \mathrm{E}$ ) in Myanmar (Burma).

Etymology: From the Greek "proteros" for earlier.

Comments: The size and shape of the body and nucleus resemble those of extant species of Endamoeba Leidy from termites and roaches [23] which are the only known hosts [16]. The nucleus appears to be dividing and some putative chromatin threads connect the two adjacent nuclear zones. A possible cyst of Endamoebites (Fig. 21) is $53 \mu \mathrm{m}$ in diameter, possesses a thick membrane, contains 13 nuclei in the focal plane shown and resembles cysts of extant Endamoeba [16].

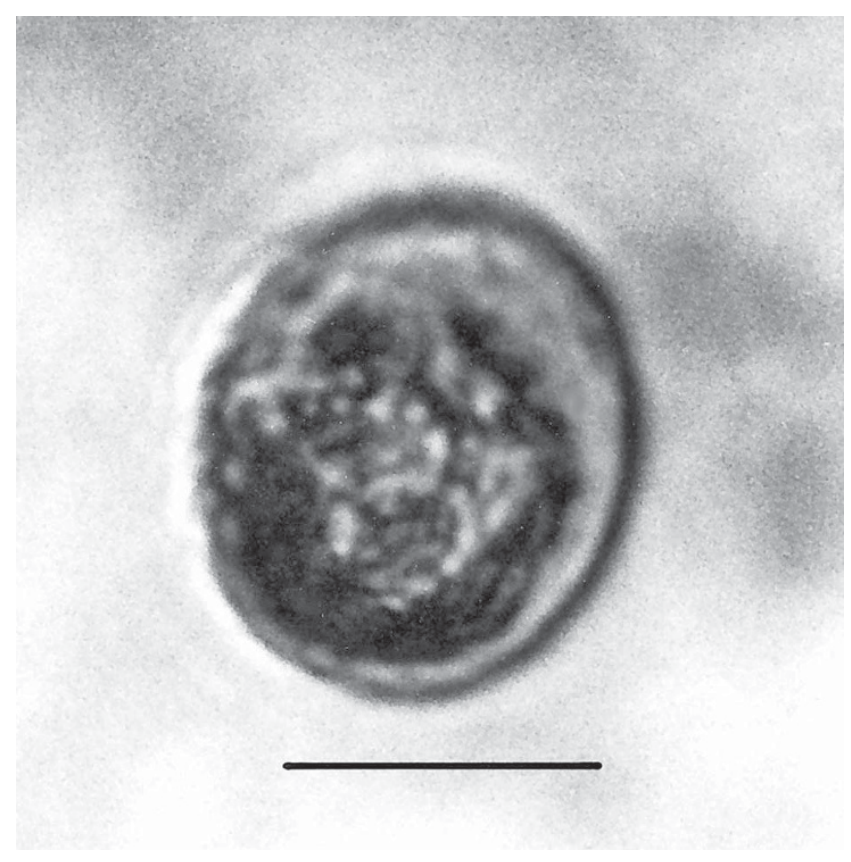

Figure 21

Spherical cyst with two or more nuclei. Bar $=14 \mu \mathrm{m}$. 


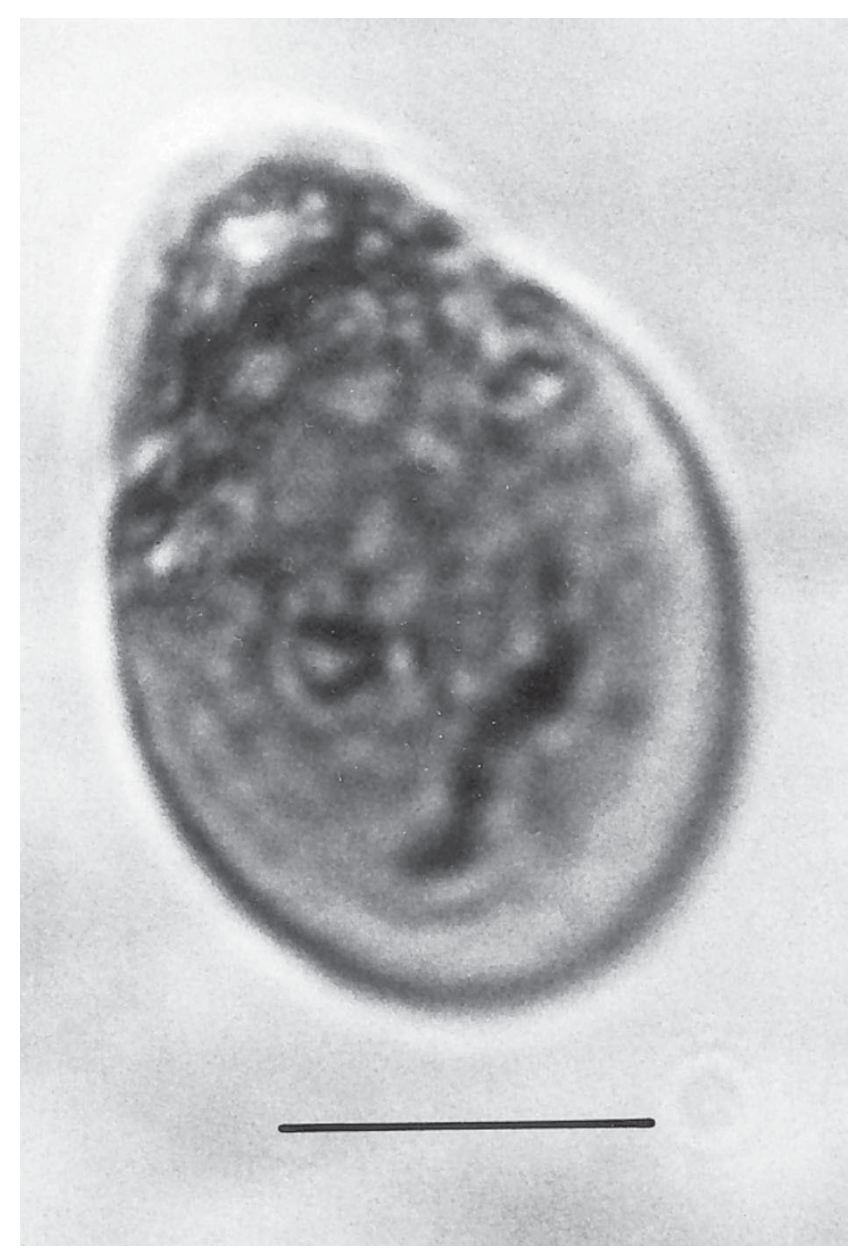

Figure 22

Pyriform cyst. Bar $=12 \mu \mathrm{m}$.

\section{Additional protists}

Additional unknown protist stages associated with $K$. burmensis are illustrated in Figs. 18, 19, 20, 22, 23, 24, 25, 26, 27, 28, 29, 30, 31 and 32. Encysted forms are shown in Figs. 18, 19, 20, 21, 22 and 23. The large (97 $\mu \mathrm{m}$ in diameter), bi-nucleated, walled cyst in Fig. 19 greatly resembles the binucleated cysts of Trichonympha described from Cryptocercus cockroaches by Cleveland et al. [[6], pg. 205, Fig. 13b]. Since these cysts were found in the amber matrix adjoining the termite, it is likely that they were already formed when the termite was entombed, especially since Cleveland et al. [6] showed that they required a period of 4 days to form in Cryptocercus. It is highly unlikely that any of the cysts were formed after the termite entered the resin, since terpinols and other chemicals would have killed the precystic, trophic stages instantly.

Unknown stages, some of which could be ciliates, are shown in Figs. 24, 25, 26, 27, 28 and 29, a flagellate in

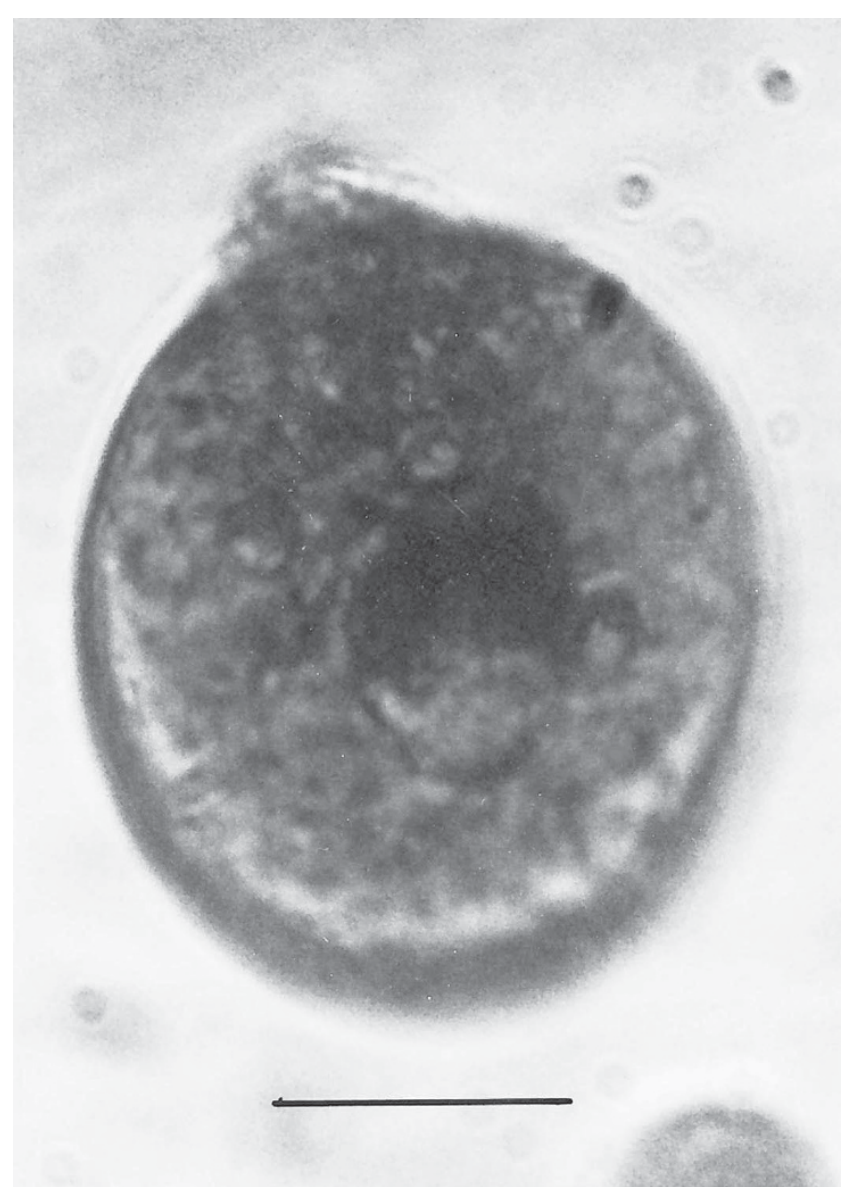

Figure 23

Spherical cyst. Bar $=14 \mu \mathrm{m}$.

Fig. 30, a pair of small elliptical cells in Fig. 29 and protists undergoing division in Figs. 30, 31 and 32. Ciliates have been reported from extant termites [24] but have not been well documented.

A pair of dauer juvenile rhabditid nematodes were also associated with $K$. burmensis. These will be described in a separate study.

\section{Discussion}

The present study represents the first descriptions of protists from a fossil termite and the earliest fossil record of mutualism involving microorganisms and animals [8]. The occurrence of an Early Cretaceous kalotermitid termite with a variety of flagellates that includes members of the same orders, families and possibly genera that occur today in kalotermitids shows considerable behavior and morphological stability of both host and protists.

Successful establishment of protozoa in xylophagous insects necessated particular attributes. The protozoa had 


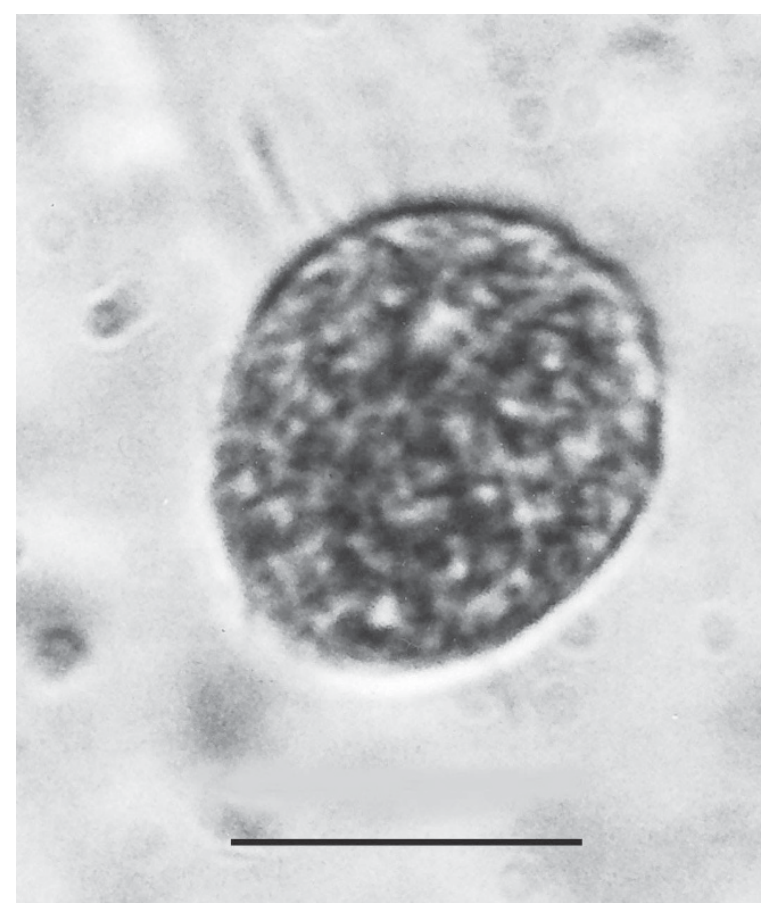

\section{Figure 24}

Possible ciliate. Bar $=14 \mu \mathrm{m}$.

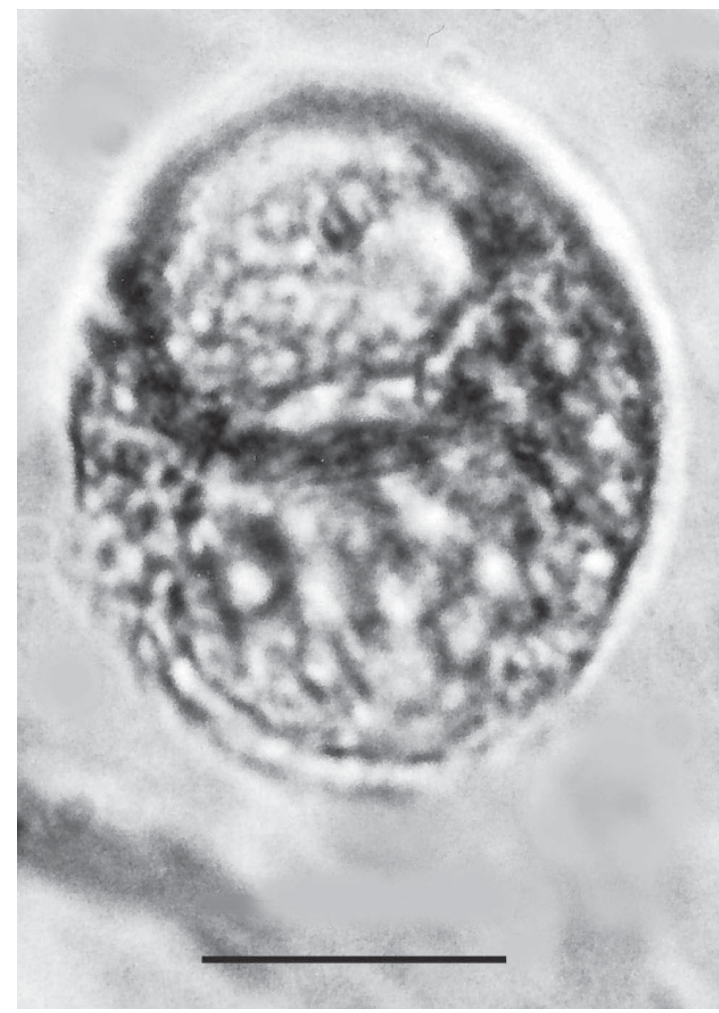

Figure 25

Possible ciliate. Bar $=12 \mu \mathrm{m}$.

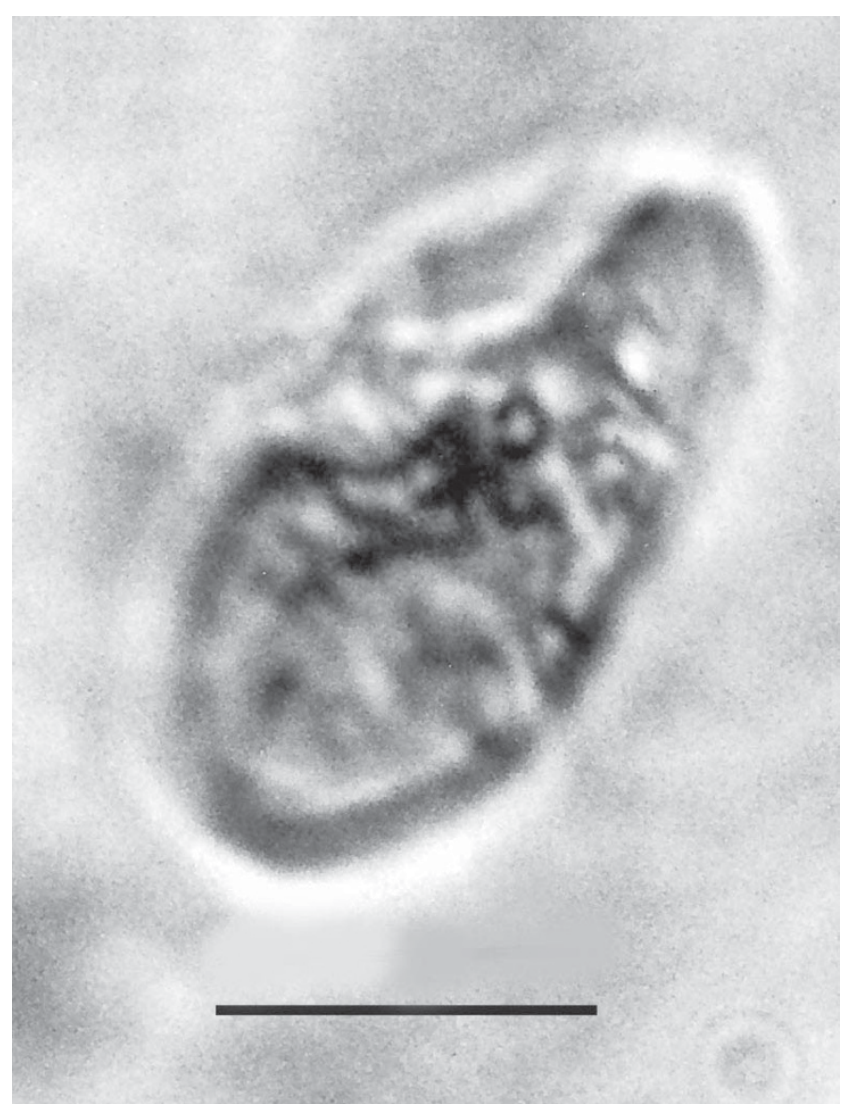

Figure 26

Possible ciliate. Bar $=14 \mu \mathrm{m}$.

to withstand the chemical and physical conditions inside the insect's alimentary tract, utilize the gut contents as a food source, cause no damage to the host, and to be carried through successive insect stages and generations. These protists apparently underwent a long period of coevolution with their hosts, since some lineages found today in the intestines of xylophagous cockroaches and lower termites are thought to have been established in Carboniferous Blattida [25].

Today, the composition of intestinal protozoa tends to be correlated with the phylogenetic position of their termite hosts and it is possible to classify families, genera and even species of termites based on their flagellates [7]. This also applies to K. burmensis, since it contains representatives of the three most abundant and widespread groups of protozoa in kalotermitids today (Trichomonada, Hypermastigida and Oxymonadea). If the systematic assignments are correct, some of the protists in $K$. burmensis appear to be restricted to other families of lower termites today. However in the Early Cretaceous, partitioning of host habitats was probably less fixed and the choice of host by a protozoan was 


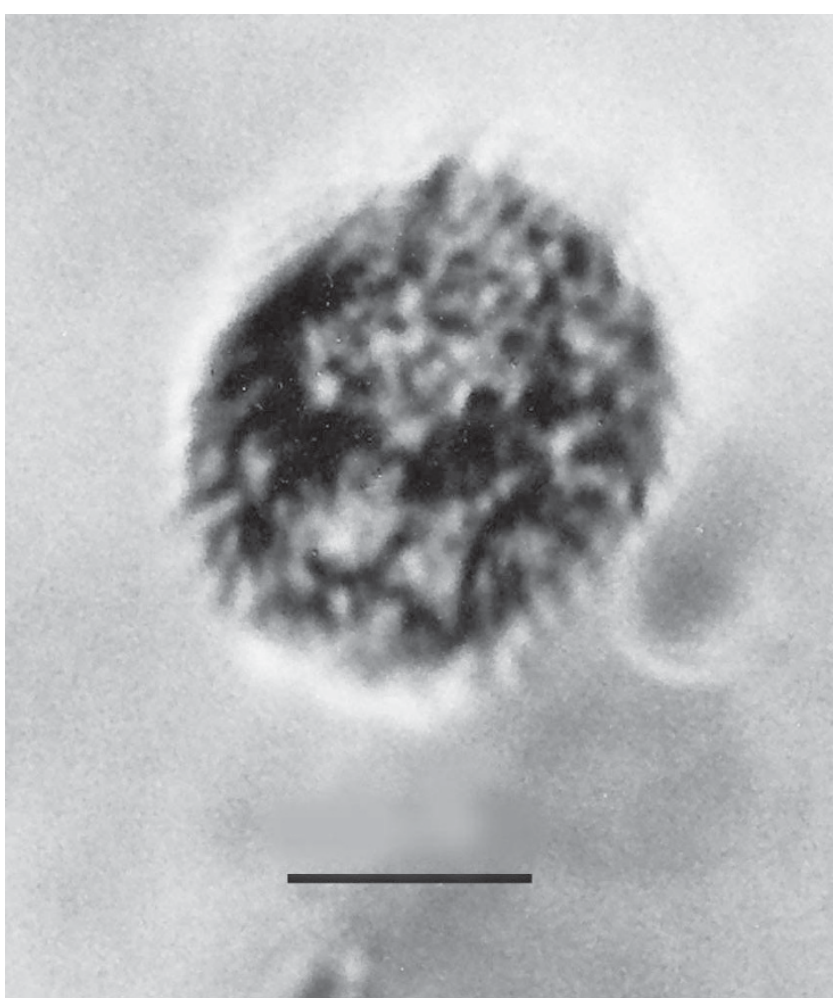

Figure 27

Possible ciliate. Bar $=10 \mu \mathrm{m}$.
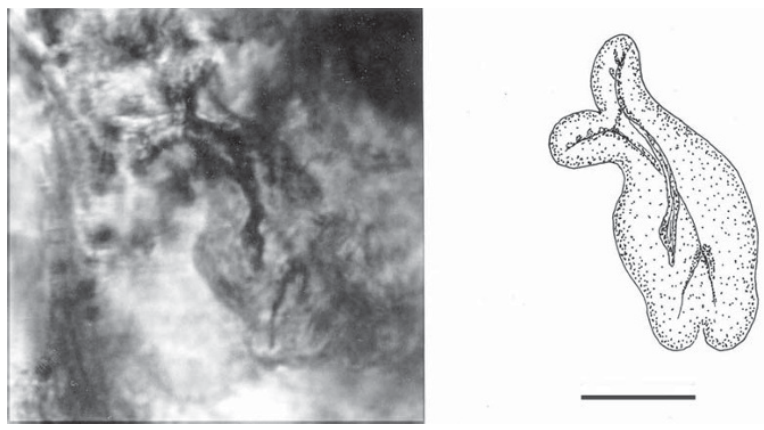

Figure 28

A, B. Photo and drawing of a dividing cell with a double rostral area, each with an axostyle. Specimen partially embedded in gut of host. Bar $=12 \mu \mathrm{m}$.

predicated largely on availability and chance encounter. Some of the protozoa described here may have been thwarted by a change in the habits of the host and since they could not adapt, disappeared from the colonies. Since angiosperms were becoming more diverse by the mid-Cretaceous, some protists in K. burmensis may have succumbed when the host diet shifted from gymnosperm to angiosperm wood. While it is assumed that most of

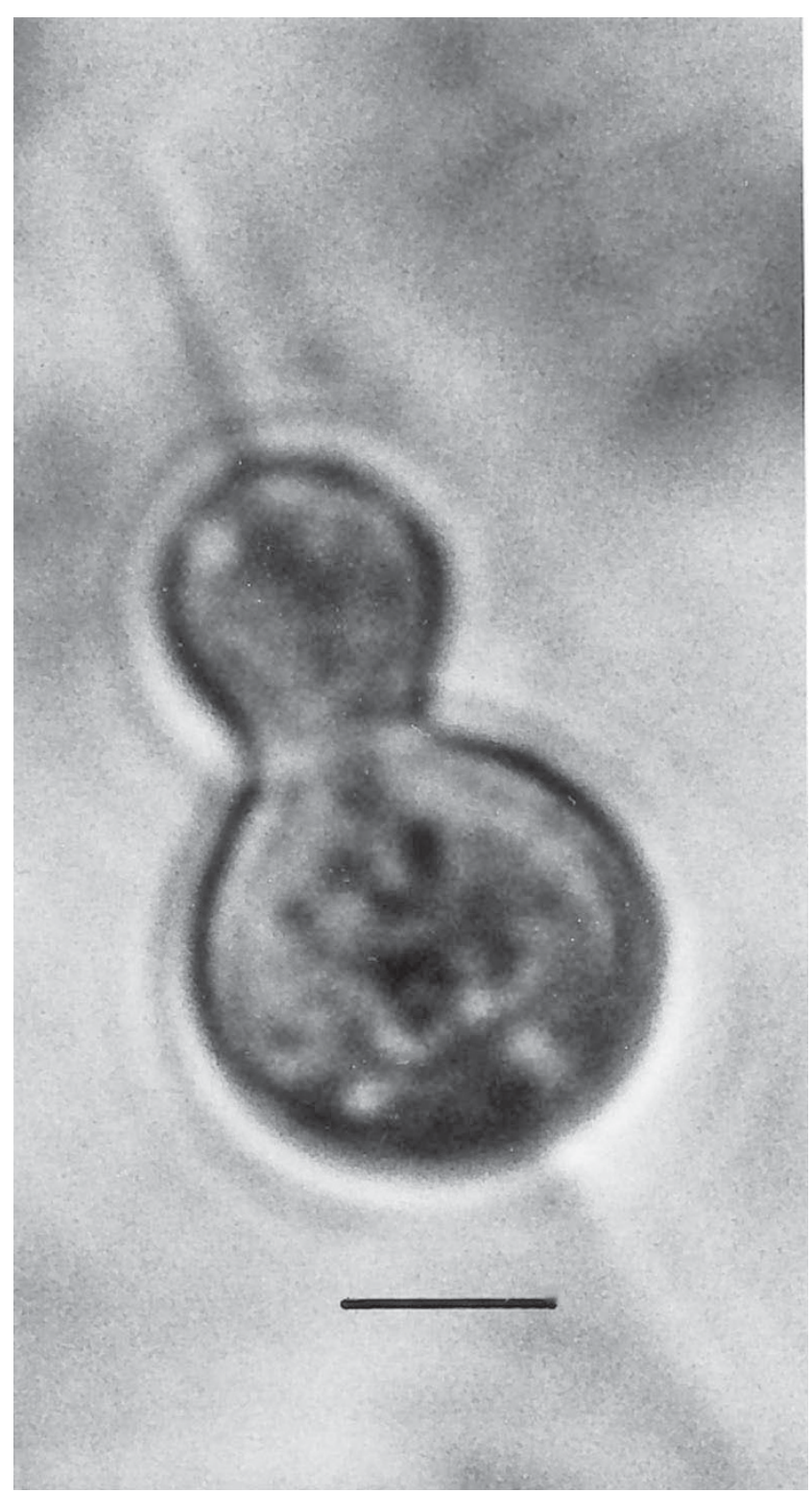

\section{Figure 29}

Example of double cell with one mastigont being extruded. Bar $=6 \mu \mathrm{m}$.

the protozoa described here had a mutualistic relationship with K. burmensis, as members of the Trichomonada, Hypermastigida and Oxymonadida do with extant lower termites, some, as for instance Endamoebites proterus, may have been simply commensals and provided no benefit to K. burmensis.

One striking difference in the behavior of the protist symbionts in extant termites and $K$. burmensis is the presence of encysted stages in the latter. In extant termites, mature protist cysts are rarely formed [26, 27] 


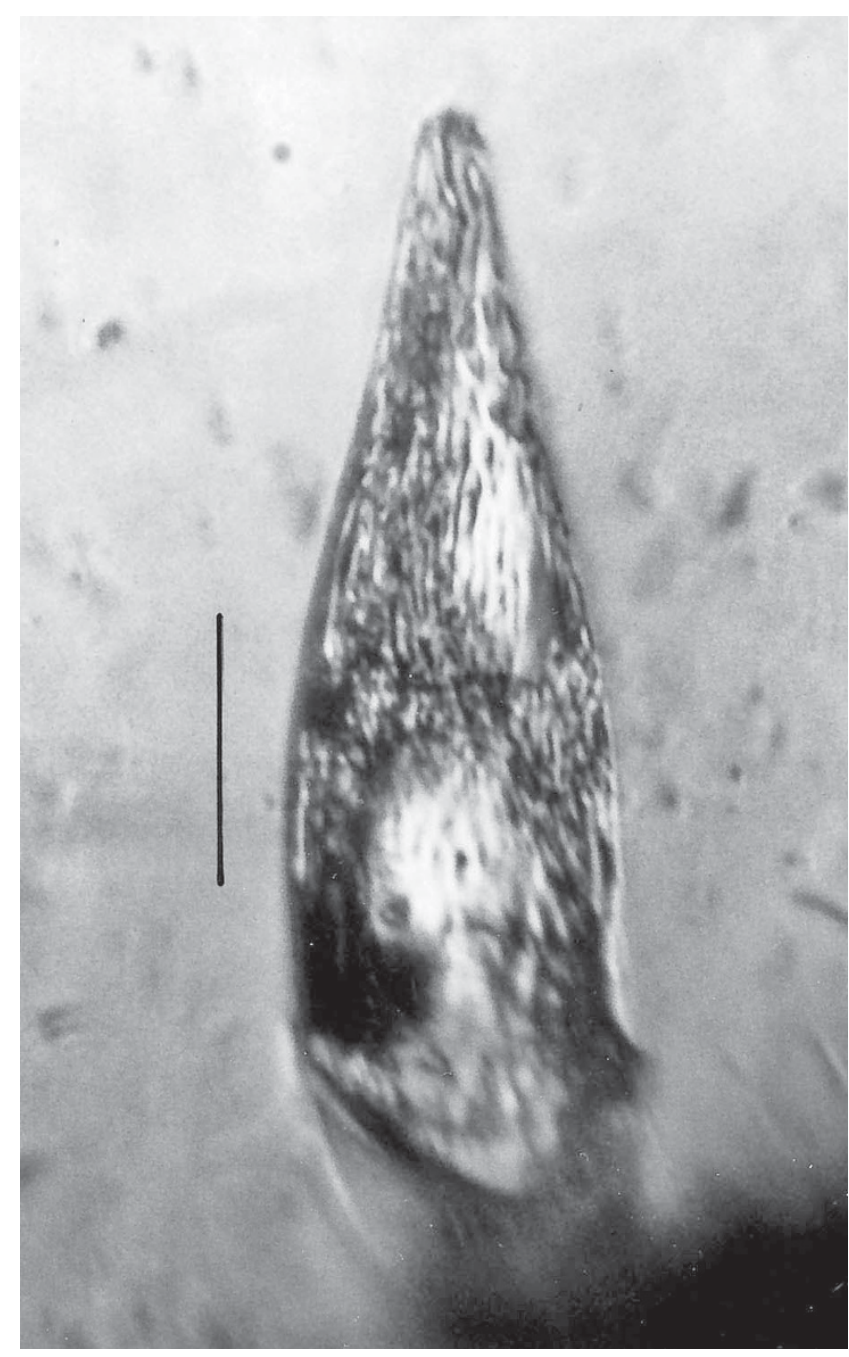

Figure 30

Unidentified flagellate, probably of the family

Trichonymphidae. Bar $=28 \mu \mathrm{m}$.

and never in alates since the flagellates are transferred to nest mates and hatchlings by proctodeal trophallaxis (intrastadial and intergenerational transfer). However it has been hypothesized that the distant ancestor of termites passed flagellate cysts to nest mates and hatchlings by coprophagy $[6,7,27-30]$.

Several possible scenarios could explain the presence of cysts in K. burmensis:

A), the colony was subsocial and ingesting cysts in fecal pellets (coprophagy) was the main method for the intrastadial and intergenerational transfer of protists; B), the colony was subsocial or eusocial and both coprophagy (ingesting cysts in fecal pellets) and proctodeal trophallaxis served to transfer the flagellates to nest

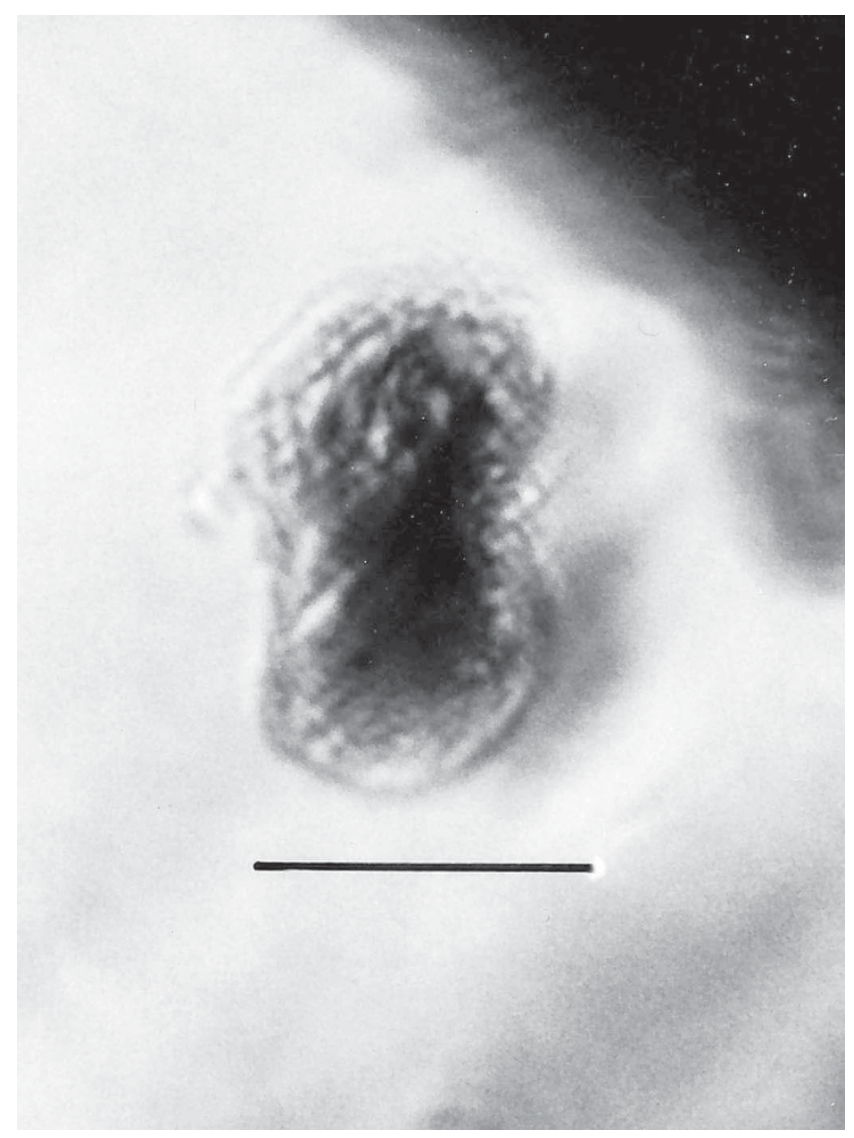

Figure 31

Cell undergoing binary fission. Bar $=12 \mu \mathrm{m}$.

mates and hatchlings; C), the colony was eusocial and protozoa were transferred by proctodeal trophallaxis. The cysts were an ancestral carry-over and represent an evolutionary dead-end; D), some of the cysts could have been ingested while feeding and had no trophic association with $K$. burmensis.

\section{Materials and methods \\ Specimens}

The amber with the fossil termite containing the protists is roughly semi-circular in outline, measuring $13 \mathrm{~mm}$ along the longest edge, $10 \mathrm{~mm}$ in width and $1 \mathrm{~mm}$ in thickness. Observations, drawings and photographs were made with a Nikon SMZ-10 R stereoscopic microscope and Nikon Optiphot compound microscope. Since all photographs were taken through the thickness of the amber matrix, it was not possible to get as close as desired to individual protists without polishing away adjacent ones as well as portions of the termite host. Therefore all photos were taken at 20x. With such a small image, it was only possible to obtain a single clear photo of the specimen since further fine adjustment produced blurry images. 


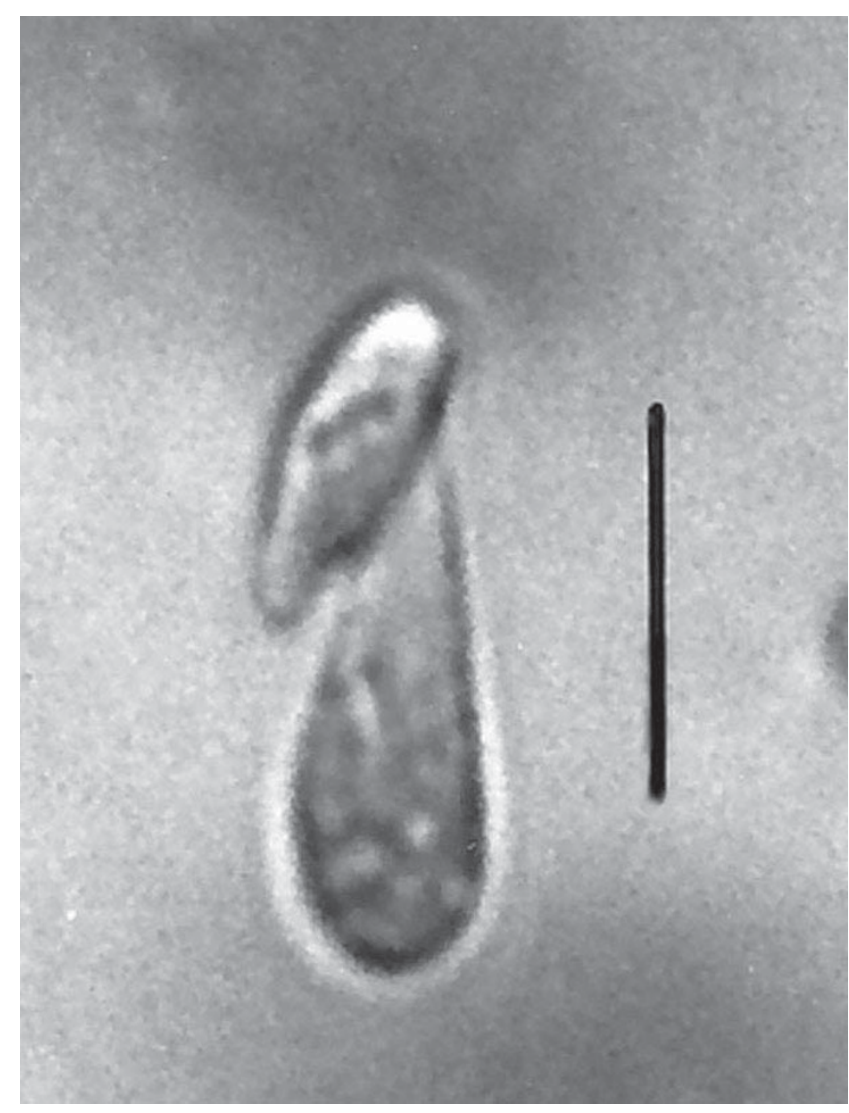

Figure 32

A pair of elliptical cells. Bar $=13 \mu \mathrm{m}$.

Adobe Photoshop was used to enlarge the photos and to obtain several modified images by using different settings of contrast, light intensity and resolution. The drawings were made from a combination of the modified images and that is why they contain more detail than the corresponding photographs, which represent the best single image obtained under the various settings. Thus Photoshop manipulation was used to replace optical sections, that were not possible to make with such small objects and at such a low magnification.

\section{Locality}

The amber was obtained from a mine first excavated in 2001 in the Hukawng Valley, southwest of Maingkhwan in the state of Kachin $\left(26^{\circ} 20^{\prime} \mathrm{N}, 96^{\circ} 36^{\prime} \mathrm{E}\right)$ in Myanmar (Burma). On the basis of paleontological evidence, this new Noije Bum 2001 Summit Amber Site was assigned to the Early Cretaceous, Upper Albian [31] placing the age at 97 to 110 mya.

\section{Type material}

In accordance with section 8.6 of the ICZN's International Code of Zoological Nomenclature, copies of this article are deposited at the following five publicly accessible libraries: Natural History Museum, London, UK; American Museum of Natural History, New York, USA; Museum National d'Histoire Naturelle, Paris, France; Russian Academy of Sciences, Moscow, Russia; Academia Sinica, Taipei, Taiwan.

\section{Source}

Nuclear magnetic resonance (NMR) spectra and the presence of araucaroid wood fibers in amber samples from the Noije Bum 2001 Summit site indicate an araucarian (possibly Agathis) tree source for the amber [32].

\section{Competing interests}

The author declares that he has no competing interests.

\section{Acknowledgements}

I thank Christine Nalepa for discussions and supplying references and Art Boucot and Roberta Poinar for reading earlier versions of the manuscript.

\section{References}

I. Ohkuma M: Symbiosis of flagellates and prokaryotes in the gut of lower termites. Trends Microbiol 2008, 16:345-352.

2. Bignell DE: Introduction to symbiosis. Termites: Evolution, Sociality, Symbioses, Ecology Dordrecht: Kluwer Academic Publishers: Abe T, Bignell DE, Higashi M 2000, I89-208.

3. Inoue T, Kitade O, Yoshimura T and Yamaoka I: Symbiotic associations with protists. Termites: Evolution, Sociality, Symbioses, Ecology Dordrecht: Kluwer Academic Publishers: Abe T, Bignell D E, Higashi M 2000, 275-288.

4. Brugerolle $\mathrm{G}$ and Lee J]: Order Oxymonadida. An Illustrated Guide to the Protozoa Lawrence, Kansas: Society of Protozoologists, Allen Press: Lee J], Leedale GF, Bradbury P 22000, 2: I I 86-I I 95.

5. Brugerolle G and Lee J]: Phylum Parabasalia. An Illustrated Guide to the Protozoa Lawrence, Kansas: Society of Protozoologists, Allen Press: Lee J], Leedale GF, Bradbury, P 22000, 2: I I 96-I250.

6. Cleveland LR, Hall SR, Sanders EP and Collier J: The woodfeeding roach Cryptocercus, its protozoa, and the symbiosis between protozoa and roach. Mem Amer Acad Arts Sci 1934, I 7:185-342.

7. Honigberg BM: Protozoa associated with termites and their role in digestion. Biology of Termites New York: Academic Press: Krishna K, Wiesner FM 1970, 2:1-36.

8. Boucot A: Evolutionary Paleobiology of Behavior and Coevolution Amsterdam: Elsevier; 1990.

9. Krishna K: A generic revision and phylogenetic study of the family Kalotermitidae (Isoptera). Bulletin American Mus nat History 196I, I 22:303-408.

10. Williams RMC: Redescriptions of two termites from Burmese amber. J Natural Hist 1968, 2:547-55I.

II. Cockerell TDA: Insects in Burmese amber. American J Sci 1916, 42:135-139.

12. Cockerell TDA: Insects in Burmese amber. Ann Entomol Soc America 1917, 10:323-329.

13. Engel MS, Grimaldi DA and Krishna K: Primitive termites from the Early Cretaceous of Asia (Isoptera). Stuttgarter Beitr Naturkunde. Serie B 2007, 37 I: I-32.

14. Emerson AE: A revision of the Tertiary fossil species of the Kalotermitidae (Isoptera). American Mus Novitates 1969. 2359: $1-57$.

15. Poinar GO Jr and Thomas GM: Laboratory Guide to insect pathogens and parasites New York: Plenum Press; 1984.

16. Patterson DJ, Simpson AGB and Rogerson A: Amoeba of uncertain affinities. An Illustrated Guide to the Protozoa Lawrence, Kansas: Society of Protozoologists, Allen Press: Lee J, Leedale GF, Bradbury P 22000, 2:804-827.

17. Kirby $\mathrm{H}$ : Systematic differentiation and evolution of flagellates in termites. Rev Sociedad mexicana Historia Nat 1949 , I 0:57-79.

18. Yamin MA: Flagellates of the Orders Trichomonadida Kirby, Oxymonadida Grassé, and Hypermastigida Grassi \& Foà reported from lower termites (Isoptera families 
Mastotermitidae, Kalotermitidae, Hodotermitidae, Termopsidae, Rhinotermitidae, and Serritermitidae) and from the wood- feeding roach Cryptocercus (Dictyoptera: Cryptocercidae). Sociobiology 1978, 4: I-I19.

19. Cross JB: The flagellate subfamily Oxymonadinae. Univ California pub Zool 1946, 53:67-162.

20. Grassé PP: Ordre des Oxymonadines. Traité de Zoologie Paris: Masson et Cie: Grassé PP 1952, I:80I-823.

21. Henry DP: Hirmocystis termitis (Leidy) and Kofoidina ovata gen. nov., sp. nov. from termites. Archiv Protistenkunde 1933, 80:101-115.

22. Hall DW and Hostettler N: Septate gregarines from Reticulitermes flavipes and Reticulitermes virginicus (Isoptera: Rhinotermitidae). J Eukaryotic Microbiol 1993, 40:29-33.

23. Kirby $H$ : Studies on some amoebae from the termite Mirotermes, with notes on some other Protozoa from the Termitidae. Quarterly J Microscopical Soc 1927, 71:189-222.

24. Kirby $\mathrm{H}$ : Protozoa in termites of the genus Amitermes. Parasitology 1932, 24:289-304.

25. Rasnitsyn AP and Quicke DLJ: History of Insects.Dordrecht: Kluver Academic Pub; 2002.

26. Dolan MF, Weir AM, Melinsky H, Whiteside JH and Margulis L: Cysts and symbionts of Staruojoenina assimilis Kirby from Neotermes. European J Protistology 2004, 40:257-264.

27. Nalepa CA: Nourishment and the Origin of Termite Eusociality. Nourishment and Evolution in Insect Societies San Francisco: Westview Press: Hunt JH, Nalepa CA 1994, 57-104.

28. Nalepa $C A$ and Bandi $C$ : Characterizing the ancestors: Paedomorphosis and termite evolution. Termites: Evolution, Sociality, Symbioses, Ecology Dordrecht: Kluwer Academic Publishers: Abe T, Bignell DE, Higashi M 2000, 53-75.

29. Nalepa CA, Bignell DE and Bandi C: Detritivory, coprophagy, and the evolution of digestive mutualisms in Dictyoptera. Insectes Soc 200I, 48: I94-20I.

30. Bell WJ, Roth LM and Nalepa CA: Cockroaches, ecology, behavior, and natural history Baltimore; The Johns Hopkins University Press; 2007.

31. Cruickshank RD and Ko K: Geology of an amber locality in the Hukawng Valley, northern Myanmar. J Asian Earth Sci 2003, 2I:44I-455.

32. Poinar $G$ Jr, Lambert JB and $W u$ Y: Araucarian source of fossiliferous Burmese amber: spectroscopic and anatomical evidence. J Bot Res Inst Texas 2007, I:449-455.

Publish with BioMed Central and every scientist can read your work free of charge

"BioMed Central will be the most significant development for disseminating the results of biomedical research in our lifetime. "

Sir Paul Nurse, Cancer Research UK

Your research papers will be:

- available free of charge to the entire biomedical community

- peer reviewed and published immediately upon acceptance

- cited in PubMed and archived on PubMed Central

- yours - you keep the copyright

Submit your manuscript here:

http://www.biomedcentral.com/info/publishing_adv.asp
BioMedcentral 